INTER NATIONAL MONETARY FUND

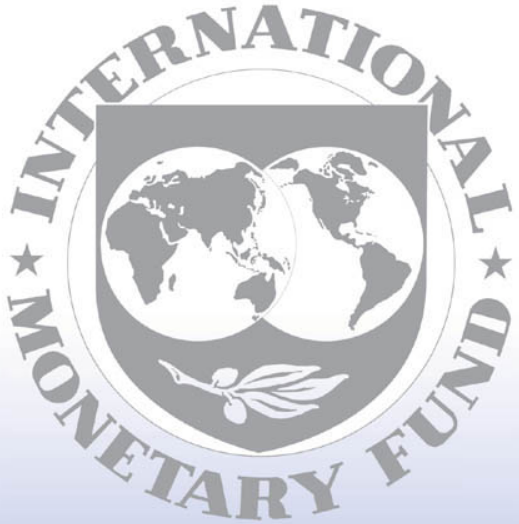

Staff

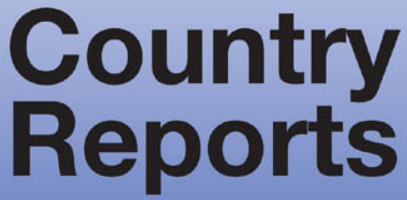


Republic of Slovenia: 2002 Article IV Consultation-Staff Report; Public Information Notice on the Executive Board Discussion; and Statement by the Executive Director for the Republic of Slovenia

Under Article IV of the IMF's Articles of Agreement, the IMF holds bilateral discussions with members, usually every year. In the context of the 2002 Article IV consultation with the Republic of Slovenia, the following documents have been released and are included in this package:

- the staff report for the 2002 Article IV consultation, prepared by a staff team of the IMF, following discussions that ended on December 18, 2001, with the officials of the Republic of Slovenia on economic developments and policies. Based on information available at the time of these discussions, the staff report was completed on March 4, 2002. The views expressed in the staff report are those of the staff team and do not necessarily reflect the views of the Executive Board of the IMF.

- a Public Information Notice (PDN) summarizing the views of the Executive Board as expressed during its March 20, 2002 discussion of the staff report that concluded the Article IV consultation.

- a statement by the Executive Director for the Republic of Slovenia.

The policy of publication of staff reports and other documents allows for the deletion of market-sensitive information.

To assist the IMF in evaluating the publication policy, reader comments are invited and may be sent by e-mail to Publicationpolicy@imf.org.

Copies of this report are available to the public from

International Monetary Fund • Publication Services $70019^{\text {th }}$ Street, N.W. • Washington, D.C. 20431

Telephone: (202) 623-7430 • Telefax: (202) 623-7201

E-mail: publications@imf.org Internet: http://www.imf.org

Price: $\$ 15.00$ a copy

International Monetary Fund

Washington, D.C. 


\title{
REPUBLIC OF SLOVENIA
}

\section{Staff Report for the 2002 Article IV Consultation}

\section{Prepared by the Staff Representatives for the 2002 Article IV Consultation with Slovenia}

\author{
Approved by Subhash Thakur and G. Russell Kincaid
}

March 4, 2002

The Article IV consultation discussions were held in Ljubljana during December 5-18,2001. The mission met Finance Minister Rop, Bank of Slovenia Governor Gaspari, members of the Finance and Monetary Affairs Committee of parliament, and other senior officials, including members of the Bank of Slovenia, the Statistics Office, and the Institute of Macroeconomic Analysis and Development, as well as representatives of the business, financial, and academic communities, and the trade unions.

The staff team comprised Mr. Demekas (head), Mr. Antolín-Nicolśs, Mr. Vamvakidis, and Ms. van Elkan (all EU1). Ms. Maver, of the office of the Executive Director for Slovenia, participated in the discussions and Mr. Prader, Alternate Executive Director for Slovenia, attended the concluding policy meetings.

Slovenia has accepted the obligations of Article VIII, Sections 2, 3, and 4 of the Fund's Articles of Agreement and maintains no restrictions on payments and transfers for current international transactions.

Slovenia has subscribed to the Special Data Dissemination Standard. Coverage, periodicity, and timeliness of the data are adequate for surveillance, and the quality of Slovenia's statistics is rapidly approaching international standards (see Appendix II).

At the conclusion of the last Article IV consultation on May 11, 2001 (EBM/01/48), Executive Directors stressed that a rapid reciuction in inflation should be the central aim of near-term policies, especially monetary policy. Directors endorsed the authorities' medium-term goal of a balanced budget, and considered that an acceleration of structural reforms would help achieve this goal, as well as prepare Slovenia for EU accession. Directors welcomed the findings of the Financial Sector Stability Assessment, encouraged the authorities to enhance competition in the banking sector, and commended their Action Plan to strengthen supervision.

The October 2000 elections retumed to power a center-left coalition headed by Mr. Dnovšek.

Slovenia is among the most advanced EU accession candidates. The EU Association Agreement came into force on February 1, 1999 and the government's National Program for the Adoption of the Acquis Communautaire is based on the target accession date of January 1, 2004. So far, 26 chapters of the Acquis out of a total of 29 have been provisionally closed. In its last Regular Report, the Commission concluded that Slovenia is a functioning market economy and provided it implements the remaining reforms to increase competition in domestic markets, it should be able to cope with the competitive pressures and market forces in the EU in the near term.

There was a joint press conference with the Minister of Finance and the Governor of the Bank of Slovenia at the end of the mission, and the authorities intend to consent to the publication of the consultation documents. 


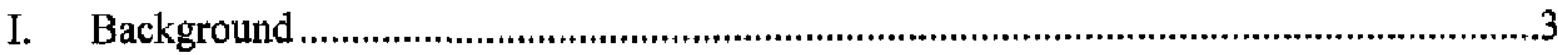

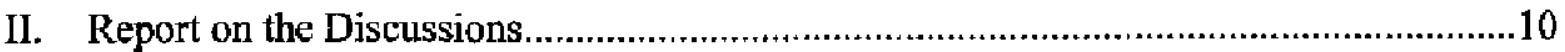

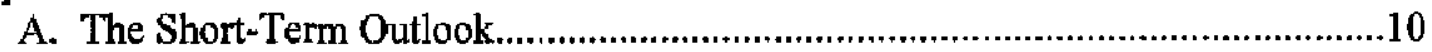

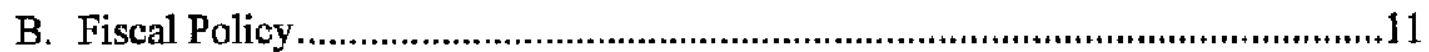

C. Monetary and Exchange Rate Policy ..........................................................14

D. Financial Sector and Structural Policies ...............................................................16

III. Staff Appraisal

Text Boxes

1. What Explains the Decline in Private Investment?....................................................

2. Pre-Accession Economic Program and Tax Reform Plans......................................8

3. New Challenges in Financial Sector Supervision ..........................................................16

Figures

1. International Comparisons, 1997-2002 ……...............................................................

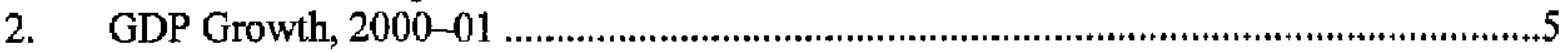

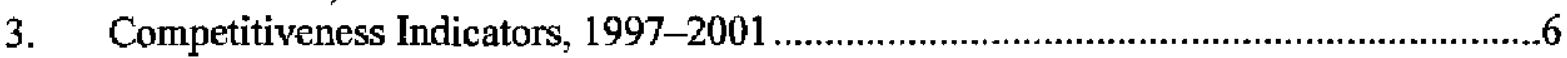

4. $\quad$ Selected Monetary Developments, 1998-2001 …......................................................

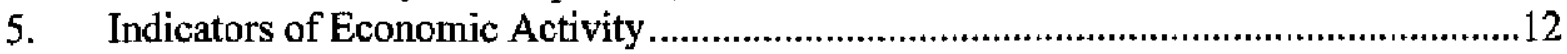

Tables

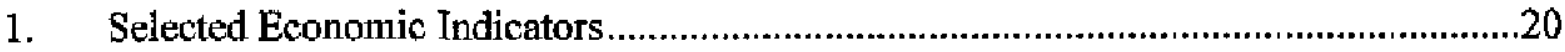

2. Balance of Payments, 1997-2002 ......................................................................21

3. Summary of General Government Operations ......................................................22

4. Staff's Medium-Term Macroeconomic Scenario, 1998-2006 ...................................23

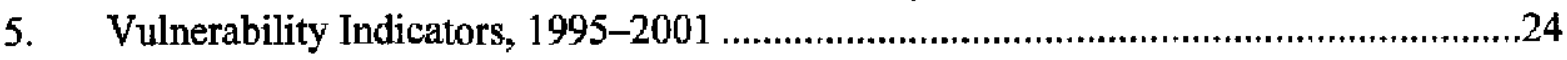

\section{Appendices}

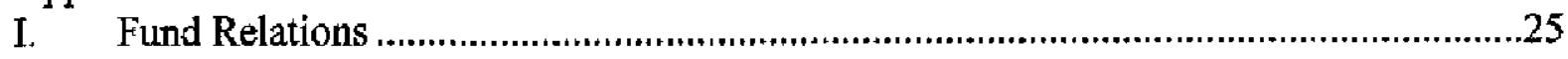

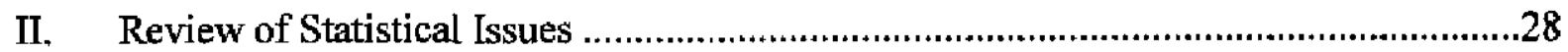

III. The Eastward Push of Slovenian Exports: Near-Term Prospects and Medium-Term Implications............................................................................................30

IV. Progress in Implementing the BoS's Financial Sector Action Plan ...........................32

V. The New Monetary Policy Framework........................................................................34

VI. Deindexation of Financial Contracts and the Saving Rate: The International Experience....................................................................................................36

VII. Foreign Bank Participation in Bank Privatization: Theory and Empirical Evidence ....38 


\section{BaCkground}

\section{Benefiting from a strong starting point and a strategy of strict macroeconomic} discipline, Slovenia is today among the most successful transition economies despite a gradualist approach to structural reform. Tight fiscal discipline and a monetary policy based on monetary targeting and a managed float for the tolar brought inflation to the single digits since 1996; kept government debt to about 25 percent of GDP; maintained strong competitiveness and a balanced current account for most of the 1990s; and earned it the highest investment rating and per capita income among transition countries (Table 1). Slovenia is also well advanced in terms of convergence and economic integration with the EU (Figure 1). However, Slovenia until recently followed a gradualist approach to structural reform. Capital controls were extensive; for most of the 1990s state banks were protected from competition by a ban on foreign branch banking and deposit rate ceilings (the two largest banks are still mostly state owned); enterprise privatization took place mostly through a voucher scheme or internal buyouts at preferential terms; and labor market regulation was extensive, including until last year full backward-looking wage indexation. Nonetheless, the relatively good starting point, stable macroeconomic conditions, and political stability through the 1990s allowed this gradualist approach to bear fruit. Following a critical report by the EU Commission in 1998, the pace of reform accelerated, although important steps still remain to be taken.

\section{Falling investment coupled with weaker demand in the main trading partners} triggered a slowdown in 2001, but competitiveness remained strong and the current account improved. Domestic demand expanded only modestly (indeed real investment declined sharply-Box 1), keeping import growth in check. At the same time, real export growth decelerated from 12.7 percent in 2000 to 7.9 percent during the first three quarters of 2001. As a result, in the first three quarters real GDP growth slowed to 3.1 percent from $4 \frac{1}{2}$ percent in 2000 (Figure 2). The resilience of exports reflected outstanding orders and an expansion into new markets in southeastern Europe and Russia, and helped narrow the current account deficit to about $1 / 2$ percent of GDP for the year as a whole (Table 2 and Appendix III). Unemployment reached an all-time low of 5.9 percent in mid-year, reflecting the lagged effects of two years of strong activity. Average real wages grew broadly in line with productivity and the depreciation of the tolar continued to improve competitiveness (Figure 3).

\section{After two years of persistent inflation, headline rates started falling in the second} half of 2001. The inflation rate had been stuck at the 9-10 percent range since mid-1999, reflecting a combination of successive exogenous shocks (VAT, energy costs, administered prices) and an accommodating monetary stance. However, the unwinding of these shocks and progressive tightening of monetary conditions during 2001 (see below) brought average inflation in 2001 down to 8.4 percent and end-year inflation to 7 percent.

4. The planned reduction in the budget deficit in 2001 did not materialize because of expenditure overruns. The 2001 budget aimed at a general government deficit of 1 percent 
Figure 1. Slovenia: International Comparisons, 1997-2002 1/ (Percent of GDP unless otherwise stated)
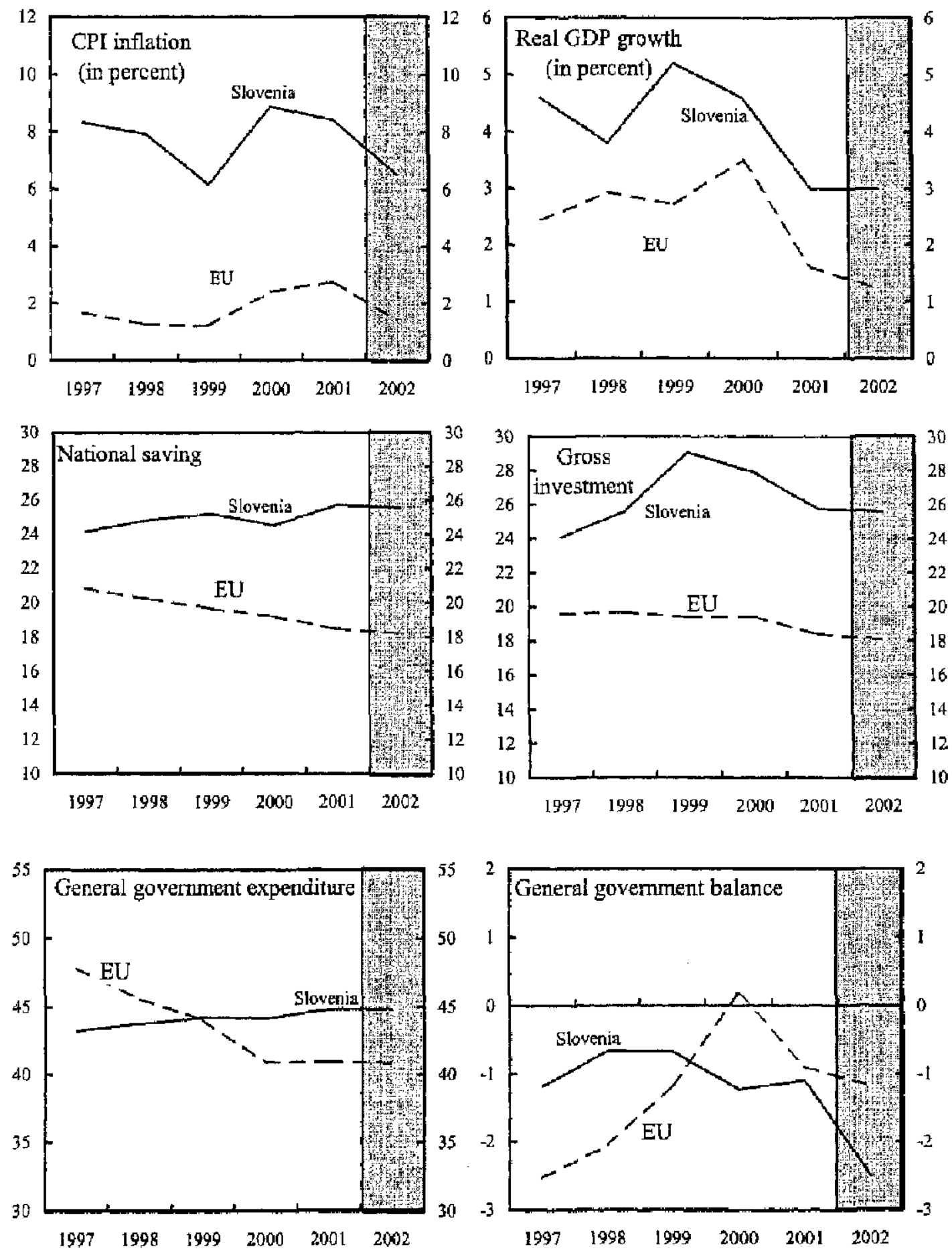

Sources: World Economic Outlook; Bank of Slovenia; and Statistical Office of the Republic of Slovenia.

1/ 2002 data are Fund staff projections. 
Figure 2. Slovenia: GDP Growth, 2000-01

(Year-on-year percent change)
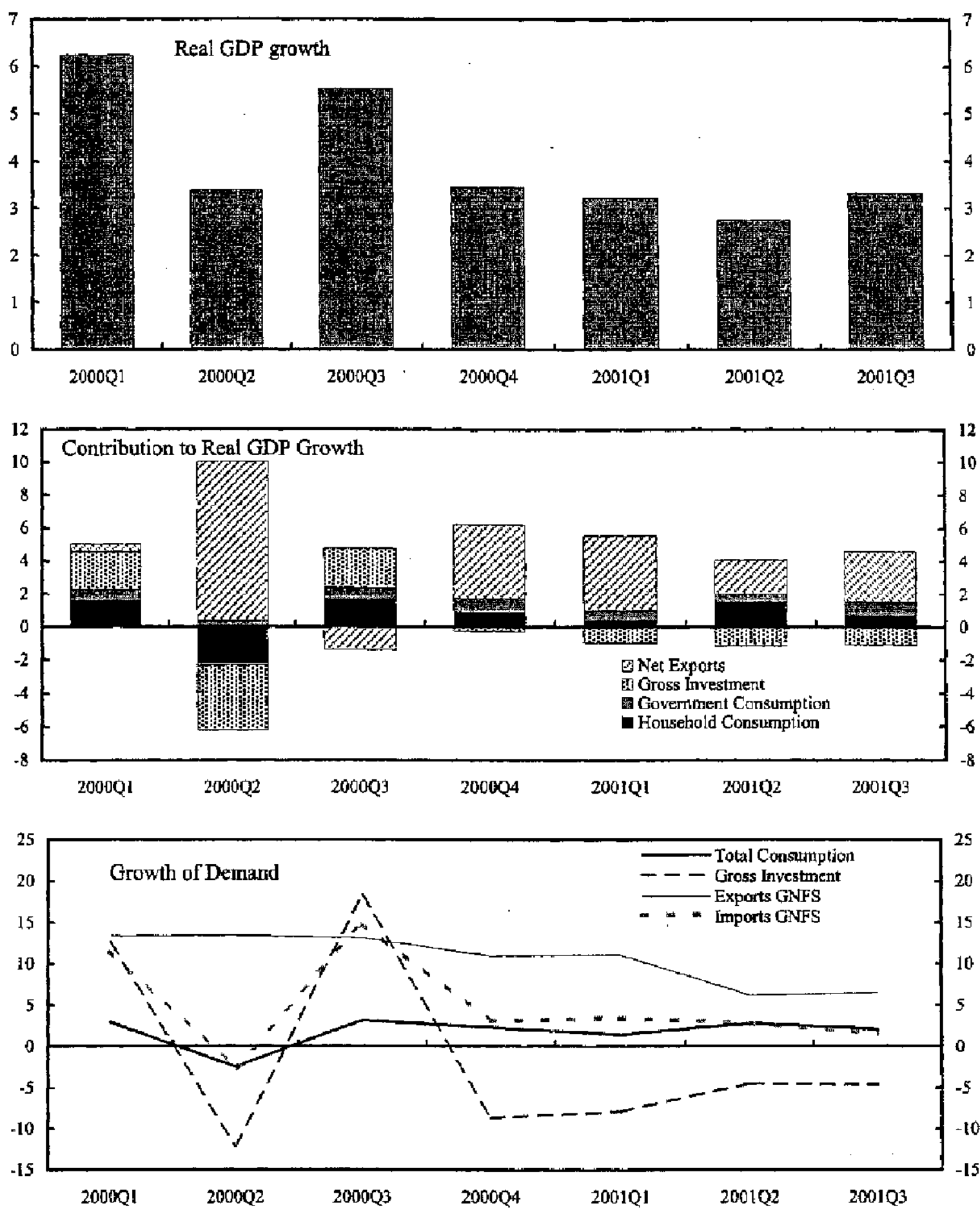

Sources: Statistical Office of the Republic of Slovenia; Fund staff calculations. 
Figure 3. Slovenia: Competitiveness Indicators, 1997-2001
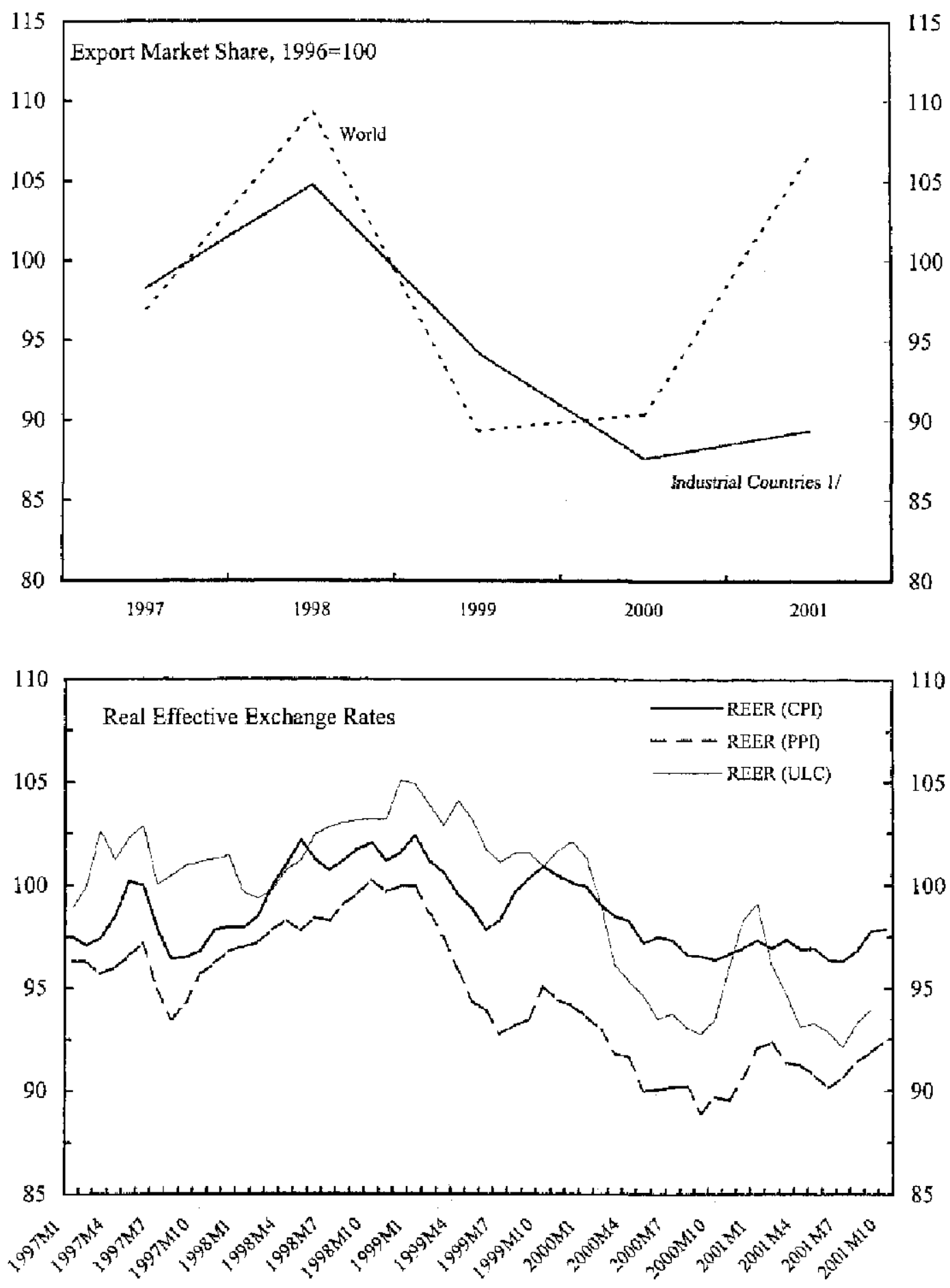

Sources: Statistical Office of the Republic of Slovenia; Fund staff calculations.

1/ Defined as the share of each country's exports to Austria, Belgium, France, Germany, Italy, Netherlands, United Kingdom, and United States. These countries account for approximately 75 percent of total exports of the countries covered. 
of GDP, down from 1.4 percent in 2000 . In the event, spending overruns reflecting higherthan-budgeted wage, consumption, and pension outlays, resulted in a general government deficit of 1.3 percent of GDP in 2001 (Table 3).

\section{Box 1. What Explains the Decline in Private Investment?}

Private investment is estimated to have declined by some 5 percent in real terms in 2001 as a whole. A number of contributing factors were identified during the discussions.

- The ownership restructuring that took place after the end of the privatization of socially owned enterprises in 1997 triggered a wave of investments for retooling and upgrading. This process is now largely over.

- The consumption boom of 1998-99 was partly financed by credit, resulting in a large increase in indebtedness of households. The adjustment of household spending in subsequent years in order to pay off this stock of debt may also have affected investment by small and medium enterprises, which is closely related to household budgets. This is reflected in a sharp decline in bank lending to the private sector since mid-1999 (see SM/02/78, Table 7).

- Business expansion in southeastern Europe triggered an outflow of foreign direct investment by Slovene companies in these countries, thereby reducing the funds available for business investment at home.

- The decline in public investment (from 4.6 percent of GDP in 1999 to 4.2 percent of GDP in 2000-01) may have also dampened private investment in areas in which there are complementarities, such as between public investment in read construction and construction of private industrial parks.

\section{The government's medium-term fiscal objective is to eliminate the budget deficit}

by 2005. This objective, reflected in Slovenia's first Pre-Accession Economic Program (PEP) submitted to the Commission in September 2001 (Box 2), is to be achieved through expenditure restraint. The planned reform of direct taxes was expected to generate some revenue losses that would be offset by an increase in the VAT rate.

\section{Monetary policy was gradually tightened during 2001, although capital inflows}

kept broad liquidity high. Interest rates were raised in March and remained unchanged until November, when they were eased as inflation pressures abated; the pace of the depreciation of the tolar slowed from an annual rate of about $8-9$ percent in the first half to $4 \frac{1}{2}$ percent in the second half; and domestic credit and base money growth were contained. This tightening of monetary conditions helped curb inflation in late 2001. However, broad liquidity - which has only a weak effect on inflation-was boosted by capital account liberalization and FDI flows. Restrictions on foreign borrowing by corporates were lifted in 1999, and those on nonresidents' investments in domestic securities and on domestic corporates holding accounts abroad in 2001, spurring an increase in foreign borrowing. ${ }^{1}$ In addition, two eurobond issues, totaling some US\$500 million, inflows for the takeovers of a mobile

\footnotetext{
${ }^{I}$ Further liberalization took place in the beginning of 2002 , with the removal of all remaining restrictions on nonresidents' investments in Slovenia. The only major remaining restriction is on individuals holding accounts abroad, which will be lifted at the time of EU accession.
} 
telecommunications company and a private local bank, and deposits of cash in euro legacy currencies pushed the M3 growth rate to 30.4 percent at end year (Figure 4).

\section{Box 2. Pre-Accession Economic Program and Tax Reform Plans}

Growth is projected to accelerate to 5.3 percent by 2006 on the assumptions of recovery in Europe and the countries of former Socialist Federal Republic of Yugoslavia (SFRY) and continued strong competitiveness of Slovene exports, underpinned by real wage moderation. Domestic savings are expected to rise and the current account deficit to stay below 2 percent of GDP.

Inflation is projected gradually to converge to EU levels, although it is expected to remain 1-2 percentage points higher due to Balassa-Samuelson effects. Nominal convergence is to be supported by tight monetary policy and structural reform, especially in certain public services (telecommunications, transport).

EU membership is assumed to take place on January 1,2004 . Pre-accession financial assistance will amount to 0.2 percent of GDP per year.

The general government is targeted to reach a balance or small surplus in 2005 . The adjustment is to take place entirely through expenditure compression (by a cumulative $21 / 4$ percent of GDP between 2001 and 2005), while the share of revenue is expected to fall by almost 1 percentage point. The adverse revenue impact of the planned reform of direct taxation (see below) would be partly compensated by an increase in VAT and excise rates.

Privatlzation proceeds, projected at about 7 percentage points of GDP during 2002-05, would be used to reduce government debt.

The PEP identifies a significant weakening of external demand as the main risk to the macroeconomic scenario. Sensitivity analysis of the projections suggests that $1 \frac{1}{2}$ percentage point lower average growth in Slovenia's main trading partners would imply about 1 percentage point lower growth in Slovenia.

A reform of direct taxes, planned for 2002, is aimed at expanding the tax base. As regards the personal income tax, the minimum income tax threshold would be raised from 11 percent to 31 percent of the average wage; child allowances would be increased; social transfers and part of interest income would be taxed; the number of tax brackets would be reduced from 6 to 4 and indexed to inflation instead of average wages; and various allowances would be transformed into tax credits. As regards the corporate income tax, the 25 percent tax rate would be maintained; the 40 percent initial allowance for investment would be halved and this amount deducted from the basis for depreciation; and a 33 percent deduction for distributed domestic source dividends would be introduced.

\section{The authorities' Financial Sector Action Plan, prepared in response to the} recommendations of last year's Financial Sector Assessment Program (FSAP), has progressed as planned. The Action Plan was aimed at strengthening financial sector supervision and enhancing liquidity management by the Bank of Slovenia (BoS) (see $\mathrm{SM} / 01 / 113$ for details). This Plan is to be fully implemented by end-2002. The details are presented in Appendix IV. 
Figure 4. Slovenia: Selected Monetary Developments, 1998-2001

Average real commercial interest rates (Percent)

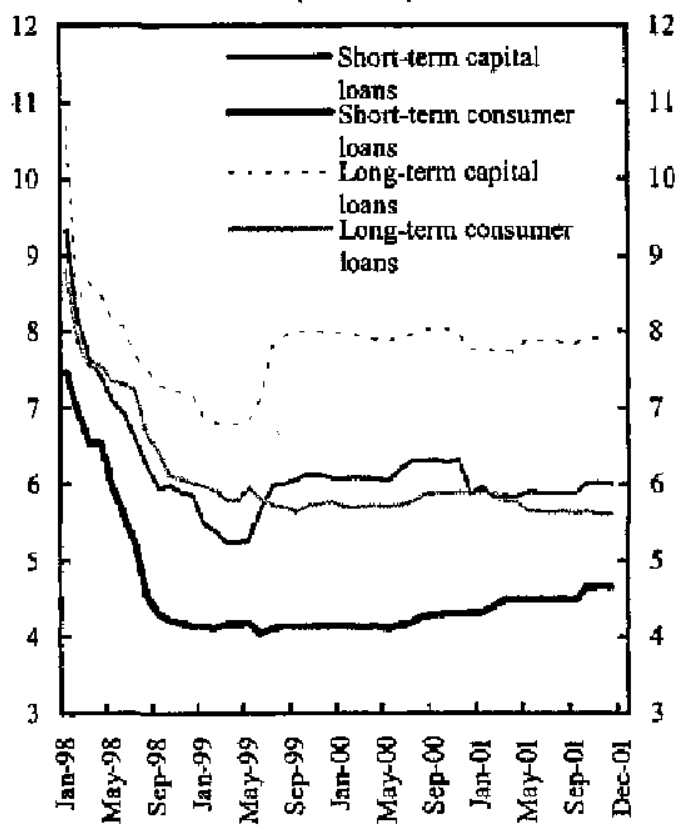

Bank of Slovenia interest rates (Percent)

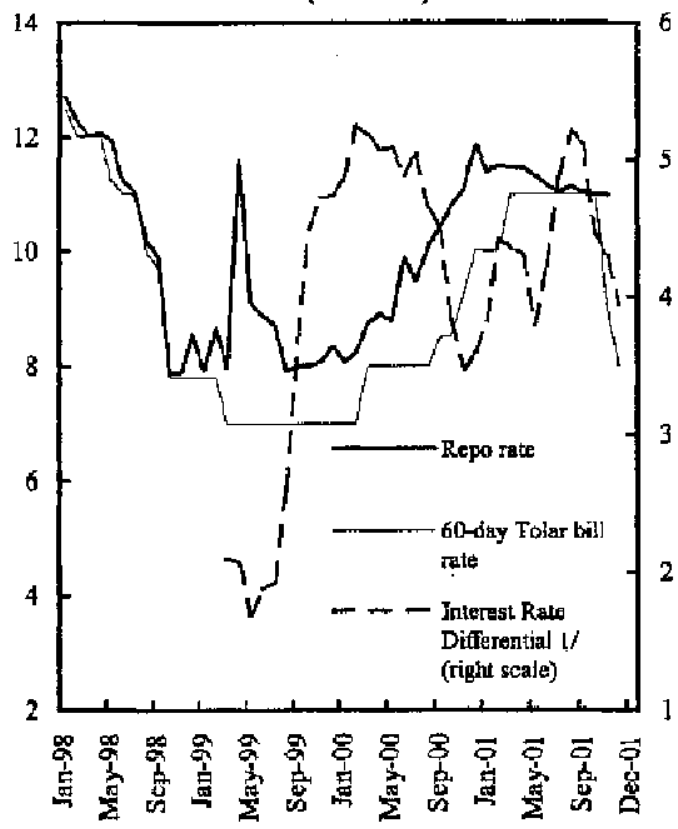

Private sector credit growth

(Year-on-year percent change)

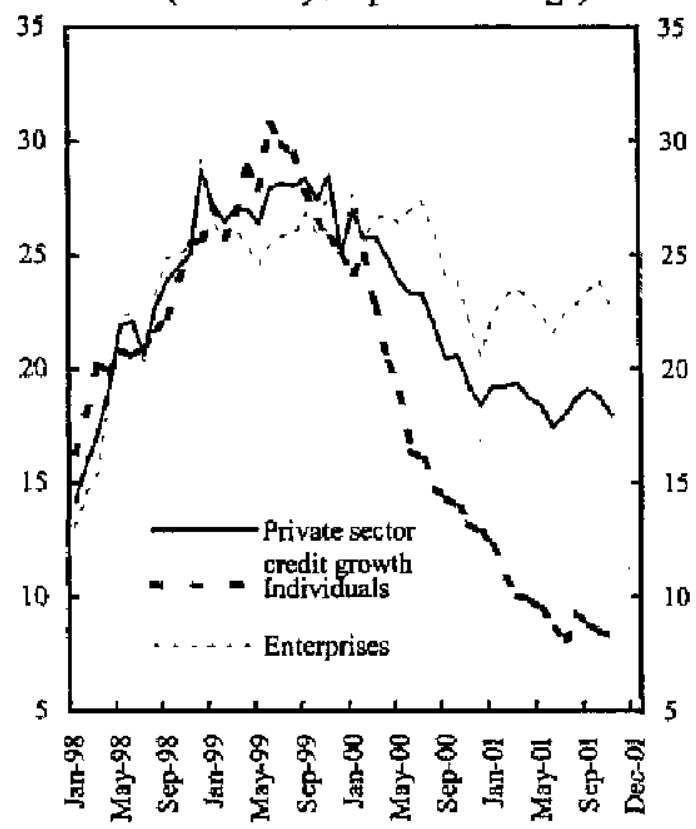

Contribution to banking sector asset growth

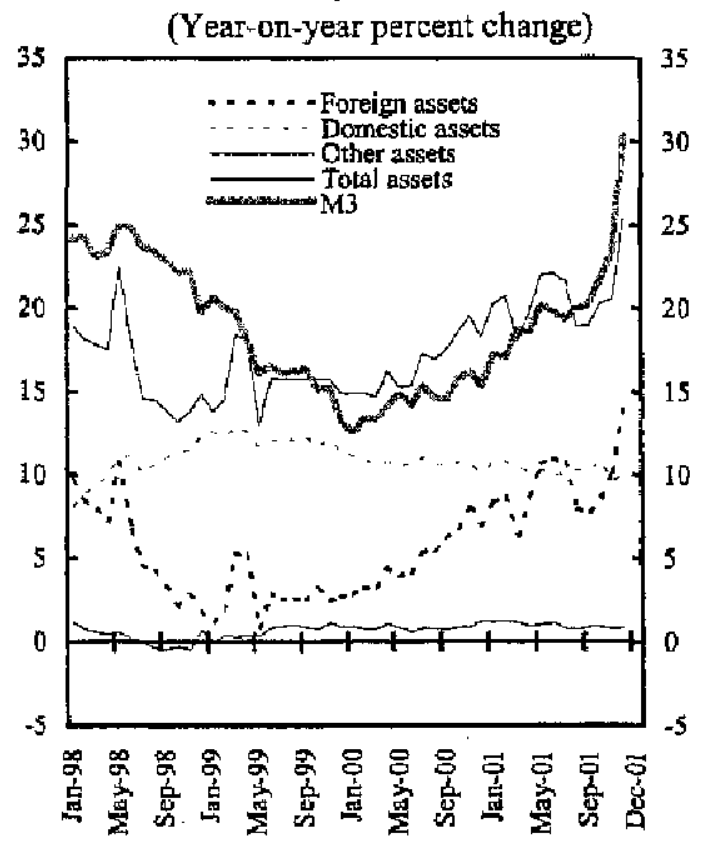

Sources: Bank of Slovenia; and Fund staff calculations.

1/ Three-month moving average of the interest rate differential between the Slovenian 60-day tolar bill rate and the ECB lending rate adjusted by the depreciation of the SIT/€ exchange rate. 2/ The sharp increase in growth of M3 and banks' foreign assets at end 2001 was due to cash in legacy currencies being deposited at banks. 
8. The pace of structural reforms accelerated in 2001 but the unfinished agenda is challenging. A new basic budget law was passed, stipulating two-year budgets starting in 2002. Backward-looking wage indexation was abandoned in favor of nearly full indexation to projected inflation (with annual symmetric adjustments for deviations of actual from expected inflation) in both the public and the private sectors in 2001 . The government decided to close the Slovene Development Corporation (SRD), a government holding company with shares in loss-making enterprises, and lowered its stake in Telekom Slovenije to 65 percent, in preparation for the future privatization of the company. However, difficult challenges still lie ahead. In particular, plans to privatize the two state-owned banks are proceeding slowly, and there is considerable opposition to foreign participation in the privatization process. Also, insurance company privatization is stalled by a court challenge.

\section{Report on the Discussions}

9. The focus of the consultation discussions was how the economic conjuncture was likely to affect the achievement of the authorities' medium-term policy objectives. Their overarching goal is to be ready for EU and ERM2 accession by the end of 2003. They reaffirmed that their macroeconomic objectives are to reduce inflation to $3-4$ percent and eliminate the fiscal deficit by 2005 . The current slowdown would help achieve the first objective but might raise the costs of achieving the second, facing the authorities with a choice between accommodating the short-run slowdown and safeguarding the credibility of the PEP. The likely extent of the slowdown and its implications for fiscal policy were thus the focus of the discussions.

\section{A. The Short-Term Outlook}

10. The authorities expected growth in 2002 to remain at more or less the same level as last year. The BoS's latest projections indicated real GDP growth at 3 percent in 2002, on the assumption of a further shallow slowdown in foreign demand compared to 2001 and a recovery in domestic investment. The latter reflected sound fundamentals, the incipient recovery abroad, and an increase in public investment. The 2002 budget, which had to be prepared on the basis of economic projections made in the early fall of 2001, assumed a modest acceleration in 2002 to $3 \frac{1}{2}$ percent. The Ministry of Finance (MoF), however, acknowledged that, given the worsening of the global outlook in the months since the budget was prepared, this estimate was perhaps on the optimistic side. Both the BoS and the MoF expected growth to return rapidly to the 4-5 percent annual range over the medium term, reflecting the global recovery and the impact of structural reforms outlined in the PEP.

11. The staff agreed that a relatively rapid recovery to historical growth rates was likely, but questioned some of the assumptions underlying the authorities' near-term projections.

- While broadly sharing the authorities' view on the prospects for investment, the staff noted that some of the factors that contributed to the fall in investment in 2001 (Box 1) were still present, and the latest confidence indicators did not show a clear 
improvement in the climate. The staff thus projected a more gradual recovery of private investment in 2002 (Figure 5).

- The authorities' export projections for 2002 and the medium term assumed that the rapid expansion into the markets of Russia and southeastern Europe would continue. The staff agreed that eastern European markets, and particularly those in former SFRY, represented an important potential for Slovene business. But it also saw limits to further near term expansion due to concerns about credit risk exposure due to a buildup in trade credits (Appendix III).

\section{In the staff's view, the unusually high uncertainty about the short-term outlook} argued for caution. In the staff's central scenario, the shape of the recovery and the sources of growth are essentially the same as those envisaged by the authorities but the pace is slower: real GDP growth is projected to slow to $2 \frac{1}{2}$ percent in 2002 and pick up only gradually toward the $4 \frac{1}{2}-51 / 2$ percent range; price pressures abate; and the current account deficit remains around $1 / 2$ percent of GDP. The authorities thought this scenario was too pessimistic on growth, but saw it as a useful benchmark for the policy discussions. ${ }^{2}$

\section{B. Fiscal Policy}

\section{The 2002-03 budget aimed at a modest reduction in the deficit to 1.1 percent of} GDP in 2002 and 0.8 percent in 2003, and a further increase in the expenditure-to-GDP ratio to just over 45 percent in 2002, which is to be unwound in $2003 .{ }^{3}$ Spending plans for 2002 were largely driven by higher outlays for border policing and defense that were dictated by Slovenia's strategic goals of EU and NATO accession, and a real increase in infrastructure investment. At the same time, to keep the pace toward their medium-term target, the authorities brought forward by one year, to January 1, 2002, the planned increase in the basic VAT rate from 19 to 20 percent (and of the lower rate from 8 to 8.5 percent), yielding an estimated $1 / 2$ percent of GDP for the full year; and intended to cut spending by almost 1 percent of GDP in 2003. Tobacco and alcohol excises were also raised in line with the schedule for harmonization of these rates to those in the EU. In total, a small discretionary withdrawal was budgeted in 2002-03.

${ }^{2}$ Data for the third quarter of 2001 that became available after the discussions, showing that private investment continued to fall, and the latest information on the global outlook can be seen as validating the staff's central scenario.

${ }^{3}$ The budget shifts accounting to full cash basis, discontinuing the practice of booking in the current year revenues accrued in December but collected the following January. This will result in a one-off shortfall in recorded revenue in 2002 estimated at SIT 75 billion and an increase in the cash deficit to 2.6 percent of GDP, but does not affect the policy stance. 
Figure 5. Slovenia: Indicators of Economic Activity
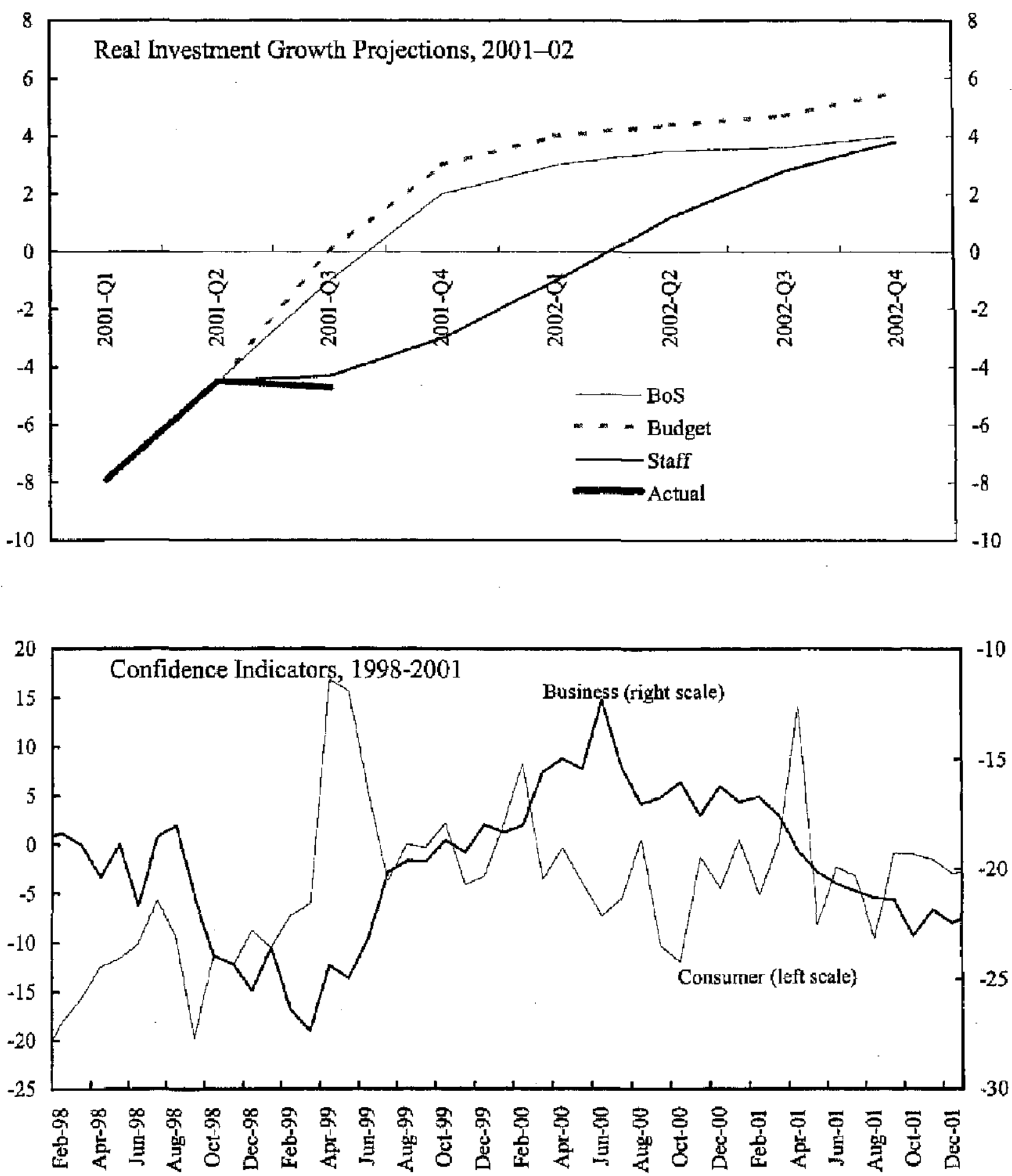

Sources: Statistical Office of the Republic of Slovenia; authorities and Fund staff projections. 
14. The deterioration in the outlook for 2002 since the budget was prepared raised the question how fiscal policy should respond to the cyclical downturn. Using its more cautious scenario as a benchmark, the staff noted that the operation of automatic stabilizers on revenue could result in a deficit of 2 percent of $\mathrm{GDP} \longrightarrow$ or $3 \frac{1}{2}$ percent including the one-off impact of the accounting shift-in 2002. Staff asked whether the government was prepared, if necessary, to submit to parliament a revised budget along these lines. The staff also questioned the advancement of the VAT rate increase in light of the cyclical conditions.

\section{The authorities acknowledged the need for flexibility in 2002 , but gave overriding} priority to their medium-term goal of a balanced budget. The budget already incorporated a degree of flexibility in the form of an authorization to borrow an additional SIT 15 billion (0.3 percent of GDP) in the event of lower-than-planned taxes due to slower growth. This would allow the operation of automatic stabilizers up to a point, and bring the deficit to about the same level as in 2001, implying a small discretionary fiscal witbdrawal. The authorities thought this would be sufficient to accommodate a somewhat weaker economy than anticipated in the budget. In the event of a deeper slowdown, such as in the staff scenariowhich they did not consider very likely - the authorities would be reluctant to allow full play to automatic stabilizers. They pointed out that the resulting increase in the 2002 deficit in such a case would jeopardize their PEP objectives, and felt that the cost in terms of policy credibility would outweigh any short-term benefits in a small and very open economy like Slovenia. They were thus prepared to cut spending in order to contain the deficit, implying a somewhat larger fiscal withdrawal than budgeted. They justified bringing forward the VAT rate hike along similar lines: this measure was part of the PEP, and was brought forward in order to allow an increase in spending - particularly investment-while keeping the deficit on a downward path. That inflation had started edging downward also made this timing propitious, while any adverse cyclical effects would be small and transient. The authorities did not rule out a re-evaluation of their budget target during 2002 in the event of a very sizeable and long-lasting downturn, but considered this a remote possibility.

\section{The staff agreed that a balanced budget was an appropriate medium-term rule for} Slovenia but underscored the importance of expenditure adjustment. While not required from the point of view of public debt or current account sustainability, a balanced budget over the cycle is consistent with balanced growth and macroeconomic stability. The staff supported the strategy of achieving a balanced budget through expenditure adjustment, but noted that the gradual creep in the expenditure-to-GDP ratio meant that greater effort was now required (more than 3 percentage points of GDP from the budgeted level for 2002 ). Thus, and given that more than three quarters of spending is pre-determined, the staff suggested that the adjustment should begin already in 2002, as illustrated in its medium-term scenario (Table 4). The staff stressed that the precise timing of achieving a cash balance was secondary to setting the expenditure ratio firmly on a downward path. This called for a more restrictive stance on public wages, pensions, and health spending, which constituted the bulk of public spending.

17. Slovenia meets the requirements of the fiscal transparency code in many important respects. As the accompanying fiscal module of a Report on Observance of Standards and 
Codes explains, the basic legislation and practices, including the provision of information, are in line with international standards, and procedures for budget preparation are quite advanced. Suggested further improvements include sharpening the definition of the general government, notably by including extrabudgetary entities that perform public policy functions; making the reporting of the overall public sector finances more comprehensive; and establishing a uniform government accounting and reporting system.

\section{Monetary and Exchange Rate Policy}

\section{A new framework has shifted monetary policy in the direction of inflation} targeting. An overhaul in the M3 targeting framework used hitherto had been rendered necessary by the process of capital account liberalization, which had diminished BoS's control over broad money and the exchange rate; and by the need to prepare gradually for the adoption of ERM2 exchange rate bands. The latter the authorities hoped to accomplish at the time of EU accession or as soon as possible thereafter, in order to limit external vulnerability and advance as much as possible the date Slovenia could adopt the euro. Furthermore, a new framework would be needed in ERM2, as the \pm 15 percent bands would provide little operational guidance for policy. In 2001, the BoS announced a new policy framework with effect from January 2002, which, albeit not formal inflation targeting, bore some of its hallmarks.

- The announcement of a medium-tern inflation objective (3-4 percent in 2005).

- The identification of the indicators taken into account in determining monetary policy, divided into two pillars: indicators of liquidity, and other economic indicators, such as the exchange rate, foreign interest rates, wages, and administered prices.

- The publication of updated BoS inflation forecasts twice a year.

In addition, an objective of the new framework is the gradual approximation of the exchange rate to a level that, upon accession to ERM2, would be appropriate as the central parity of the tolar vis-à-vis the euro (for a detailed discussion of the new framework, see Appendix V).

\section{In 2002, the BoS intended to capitalize on the opportunity provided by the easing of} exogenous price pressures to consolidate the downward trend in inflation. Achieving the inflation objective of the new framework was critical for early entry into ERM2. Therefore, the BoS intended to take advantage of the fall in oil prices and continuing softness in domestic demand to make significant progress in disinflation during 2002, aiming at an inflation rate of under 6 percent by year-end (including the one-off impact of the VAT rate hike, estimated at less than 1 percentage point). To achieve this, the BoS would maintain a cautious policy, reducing interest rates only insofar as foreign interest rates allowed it and domestic price developments were consistent with the inflation target.

20. The staff thought the new framework represented an improvement in terms of transparency, but noted that it was still highly discretionary. The announcement of an 
explicit inflation objective and the greater transparency the new framework imposed on the BoS were clear improvements over past practice. Furthermore, the policy tightening during 2001 and intended stance for 2002 were appropriate given the recent persistence of inflation and the expectation that the recovery would start during 2002 in conditions of a historically tight labor market. However, in the absence of a single intermediate target or a formal inflation targeting framework, the room for policy discretion remained substantial. How would the BoS use this framework in practice?

\section{The BoS argued that a discretionary approach was necessary in the case of} Slovenia, but stressed that price stability remained its primary goal. The exchange rate was a key price in a small, open economy like Slovenia. Furthermore, because the indexation of interest rates to inflation and significant rigidities in the money market hampered policy transmission through interest rates, foreign exchange market intervention was one of the most effective short-term policy instruments. Finally, Slovenia intended to enter ERM2 soon, and the choice of central parity would be critical for external sustainability and internal balance. Therefore, a policy of "benign neglect" of the exchange rate in the intervening period was neither feasible nor desirable. However, the BoS felt it was premature to choose the exchange rate at which Slovenia could enter ERM2 (which would also be subject to agreement with the EU and ECB). Moreover, committing to a specific exchange rate level or path would trigger unhedged borrowing at home and could be tested by the markets. The BoS thus intended to follow a pragmatic approach to monetary and exchange rate policy-as indeed it always had. In the case of capital inflows, the BoS intended to use short-term exchange rate variability and sterilization to insulate the domestic economy; but if the inflows persisted, the $\mathrm{BoS}$ would focus on its price stability objective and allow the exchange rate to appreciate. The decision whether to transform the new framework into formal inflation targeting could be taken only after three requirements were met: first, the BoS would need to develop the ability to forecast inflation accurately and affect the inflation outcome reliably; second, the BoS would need to establish a credible communications policy; and third, coordination with fiscal and administrative price policies would need to be improved.

\section{The new framework underscored the importance of deindexing financial contracts} and improving the functioning of the money market. The authorities and the staff agreed that deindexing financial contracts and developing the money market were crucial for improving the transmission of monetary policy through interest rates and enhancing its effectiveness. The staff also saw it as a necessary precondition for moving toward a formal inflation targeting framework, which, as a more rules-based system, would bolster policy credibility. A number of key steps had been taken in this direction. First, a new law deindexed all new financial contracts with maturity less than a year as of July 2002 as a first step toward complete financial deindexation. Second, the indexation revaluation was effectively removed from the Slovene accounting standards in December 2001, thus eliminating an incentive for corporates to demand indexed contracts. Third, the BoS restructured its intervention instruments during 2001 to improve liquidity management, in line with the Financial Sector Action Plan (see Appendix IV). Fourth, the BoS and the MoF agreed on a joint plan to develop a money market: weekly auctions for one-month T-bills 
were started in May 2001, and steps were underway to establish a secondary market. The BoS was concerned that hasty moves toward deindexation might depress savings. The staff, however, argued that, as international experience showed (Appendix VI), deindexation would not affect private saving, provided it was accompanied by successful disinflation.

\section{Financial Sector and Structural Policies}

\section{Implementation of the measures included in the Financial Sector Action Plan had considerably strengthened and rendered more sophisticated financial sector supervision.} The Action Plan (Appendix IV) had resulted in a number of improvements, notably in addressing the main supervisory challenge in the Slovene financial sector: its interconnectedness. However, the combination of the maturing of Slovenia's financial sector-which was approaching the depth and sophistication of that in Western European countries-with capital account liberalization and consolidated supervision was creating new challenges for the $\mathrm{BoS}$ (Box 3 ).

\section{Box 3. New challenges in Financial Sector Supervision}

The supervision of Slovene banks' subsidiaries in foreign countries (which is the primary responsibility of the foreign supervisor) required familiarity with differences in the legal frameworks, supervișion practices, and business cultures in foreign countries. Despite the formal Memoranda of Understanding, cooperation with foreign supervisors was often challenged by differences in supervision approaches. BoS's approach was more rules-based than that of other supervisors (such as, for example, the approach of the German bank supervision agency to country exposure limits).

The supervision by the BoS of nonbanking companies that were owned by banks required new skills of the supervisors. It also resulted in an uneven playing field among nonbanking companies: companies in real estate, insurance, leasing, manufacturing, and other nonbanking industries that were not owned by banks were not subject to the restrictive rules imposed by $\mathrm{B}$ oS.

The enforcement of strict rules on connected lending was a difficult task in a small economy like Slovenia, as major banks, in particular, could not easily find clients who were not connected to their shareholders. This problem was magnified by consolidated supervision, as such rules now also applied to nonbank institutions owned by banks.

\section{A more competitive environment was accelerating consolidation in the banking} system, but bank privatization remained the key condition for success. The elimination of barriers to entry for foreign banks in the late $1990 \mathrm{~s}$ and the ongoing capital account liberalization were intensifying competitive pressures in the Slovene financial sector. As a result of a process of mergers and takeover, the number of banks has fallen from 33 in the mid-1990s to 25. More consolidation was expected in 2002, as some merger and acquisition proposals were already in line for approval. The authorities and the staff agreed that consolidation was a necessary step toward a stronger financial sector. The negative impact on competition would be more than offset by foreign intermediaries competing for local business directly through the liberalized capital account. But consolidation would never be complete or successful without the sale of the majority state holdings in the two largest Slovene banks. The authorities had started the process of privatization: according to a plan 
approved in 2001, the state should sell 65 percent of NKBM and 48 percent of NLB (reducing state holdings in the latter to 25 percent) in 2002 . Bids had been received, including from a number of well-respected international financial institutions, and negotiations with the preferred bidders were planned to be completed by March. However, there was considerable domestic opposition to foreign participation in bank privatization.

\section{The staff underscored the goals that should guide bank privatization and supported} a policy of no discrimination against foreign investors: The process should aim at (i) creating banks that were strong, competitive, and flexible not only in Slovenia, but in a broader European context; (ii) finding core shareholders or strategic investors who have experience in the banking industry and could guarantee good corporate governance; and (iii) ensuring that privatization takes place in a transparent manner. As long as these principles were satisfied, it was immaterial whether the new owners were domestic or foreign. However, finding qualified strategic investors in a small country like Slovenia might be difficult. The staff thus urged the authorities to avoid discriminating against foreign investors. Indeed, international experience suggested that the long-term benefits of foreign participation in bank privatization could be significant (Appendix VII).

\section{Major structural reforms had been initiated and needed to be brought to successful} conclusion. The authorities outlined an ambitious structural reform agenda, and the staff urged them to maintain the momentum and bring them to a close soon. In the area of privatization, besides banks, the government planned to proceed with the telecommunications company, the steel company, and - once the legal problems are resolved-the insurance companies. The SRD was to be closed in early 2002 . A new corporation would take over some of the functions of the SRD and liquidate the rest, but would not be able to perform lending activities. The assets remaining after the settlement of the SRD's liabilities will be transferred to the treasury. And in the labor market, the replacement of backward-looking with forward-looking indexation was a major step forward in reducing inflation inertia. Two important next steps were now to (i) promulgate the draft Labor Relations Law that liberalized employment protection legislation (on which agreement had recently been reached between employers and unions); and (ii) reform the public wage determination system in the context of the Law on Wages of Public Sector Employees, currently under preparation, by replacing the current system with a simple, transparent scale and performance-based awards.

\section{STAFf APpraisal}

27. Macroeconomic management in 2002 is challenged by considerable economic uncertainty. Although the slowdown is likely to be relatively short-lived, with the recovery starting during the year, real growth in Slovenia in 2002-03 is likely to be below the current range of official forecasts. Projections, however, are clouded by unusually high uncertainty. Indeed, uncertainty is the major feature of the current economic conjuncture.

\section{The authorities' intention to keep policies focused on medium-term goals is} appropriate. The export-oriented private sector is the only viable engine for sustainable 
growth in Slovenia. Macroeconomic and structural policies should not attempt to fine-tune and micromanage the economy, but create a stable enabling environment for private sector development.

\section{The benefits of fiscal automatic stabilizers would be relatively limited and} outweighed by the costs of a rapidly rising deficit. In a small and very open economy like Slovenia, automatic stabilizers on the revenue side could provide only a weak cushion for economic activity. The sudden jump of the deficit to historically unprecedented levels would risk undermining policy credibility. The government's intention to limit the operation of automatic stabilizers in 2002 is thus appropriate. Given the short-term outlook, this is likely to require restraining expenditure relative to budgeted levels.

30. A balanced budget over the cycle remains the right medium-term goal for Slovenia, but policy should now focus on putting expenditures firmly on a downward path. A balanced budget is consistent with balanced growth and macroeconomic stability, as well as with Slovenia's aspiration to accede to EMU as quickly as possible. The tax reform plans, which appropriately focus on expanding the tax base, will reduce tax revenue, making critical the need to reverse the recent upward creep in the expenditure-to-GDP ratio. The rolling twoyear budget framework provides a vehicle to achieve this, and should be supplemented by a fully fledged medium-term expenditure plan. Spending needs associated with EU and NATO accession should be met through resource reallocation. This implies that the share of public wages and social transfers, which constitute the bulk of public spending, must be reduced. For this tradeoff to be acceptable and sustainable, reforms are needed to make public wage determination less arbitrary, curtailing the risk of wage spirals in the government, as well as improve the efficiency and targeting of social transfers. Putting the expenditure-to-GDP ratio on a downward path is more important than the date of achieving the balanced budget goal.

\section{The new monetary policy framework sets an explicit inflation goal, but its} effectiveness and credibility in achieving it are yet to be proven. Since the new framework remains highly discretionary, the BoS must establish a track record of consistent antiinflationary stance. The first test will be in 2002. The unwinding of the external price shocks and the adoption of forward-looking wage indexation provide an opportunity to break the persistence of inflation, despite the VAT rate hike. The wage indexation catch-up clause makes achieving the inflation goal more important. To meet this challenge, the BoS should keep policy tight, as monetary easing would risk creating conditions for a resumption of price pressures once growth picks up. The focus should remain on disinflation and, especially in the event of large capital inflows, the exchange rate should be subordinated to this goal. The BoS should use the regular inflation reports to communicate to the public the importance of focusing on disinflation and to explain the steps it takes with reference to that goal. Moving gradually toward more formal inflation targeting would enhance policy credibility and provide an effective framework for policy within the ERM2 bands.

32. The authorities' Financial Sector Action Plan is notable for its thoroughness and ownership. The Action Plan, designed by the BoS to address the weaknesses identified by the FSAP, is close to full implementation. In the future, the authorities need to gain 
experience that will allow them to tackle the supervisory challenges that arise in the new, liberalized and highly integrated financial sector.

\section{Privatization is a necessary condition for a more efficient and competitive banking} system. While consolidation is advancing under the pressure of competition, without the privatization of the two largest banks, the Slovene banking system will be at a disadvantage in the broader European context. The concerns regarding foreign ownership are not borne out by international experience and are inconsistent with the free market philosophy underlying Slovenia's reforms. Discriminating against foreign investors would not only risk stalling the bank privatization process, but would also discourage foreign investment and send the wrong signal to the rest of the world about the kind of economy Slovenia wants to build.

\section{The recent momentum behind structural reforms should be maintained, and} pending liberalization and deregulation measures brought to conclusion. Major progress was achieved in the labor market with the adoption of forward-looking wage indexation. The market needs now to be made more flexible and efficient through passage of the draft Labor Relations Law. The public sector labor market, in particular, should be given a new, transparent, and fair wage determination mechanism that is not hostage to the power of entrenched interests. This would not only help restore control over the government wage bill, but also allow a more rational management of human resources in the public sector. Finally, greater effort is required to reduce the state's involvement in economic life through deregulation and closure of extrabudgetary funds, or limiting their operations to public policy functions. The same rule should apply to the entity that would succeed the SRD.

35. The next Article IV consultation with Slovenia should remain on the 12-month cycle. 
Table 1. Slovenia: Selected Economic Indicators

\begin{tabular}{|c|c|c|c|c|c|c|}
\hline & 1997 & 1998 & 1999 & $20 \times 0$ & $\frac{2001}{\text { Pret. }}$ & $\frac{2002}{\text { Staff Proj. }}$ \\
\hline Delutand and Supply If & \multicolumn{6}{|c|}{ (Contribution to annus] growth) } \\
\hline Dompertic demsand & 4.9 & 6.1 & 9.4 & 1.1 & 0.1 & 2.1 \\
\hline Private consurnption & 3.6 & 1.9 & 3.4 & 0.4 & 0.8 & 1.0 \\
\hline Public comaumption & 0.9 & 1.2 & 0.9 & 0.6 & 0.7 & 0.6 \\
\hline Gross investrment & 24 & 3.1 & 5.1 & 0.1 & .1 .5 & 0.5 \\
\hline Foreign balance & -0.3 & -2.3 & -4.2 & 3.4 & 3.0 & 0.4 \\
\hline Exports of goods and nontzetor setrices & 6.4 & 4.0 & 1.1 & 7.4 & 4.5 & 2.6 \\
\hline \multirow[t]{2}{*}{ Thiports d f pods atd nonfactor services } & 6.7 & 6.3 & 5.3 & 4.0 & 1.5 & 2.2 \\
\hline & \multicolumn{6}{|c|}{ (Anzul percentage change') } \\
\hline Real GDP $1 /$ & 4.5 & 3,8 & 5.2 & 4,6 & 3.1 & 2.5 \\
\hline P rivade consuruption & 2.8 & 3.3 & 6.0 & 0.8 & 1.6 & 15 \\
\hline Public tomsemption & 4.3 & 5.8 & 4.6 & 3.1 & 3.3 & 3.4 \\
\hline Gross inwestment & 10.4 & 12.4 & 18.9 & D.5 & .5 .7 & $\mathrm{t} . \mathrm{A}$ \\
\hline Expors of goods and monfactor serviter & 11.6 & 8.7 & 1.7 & 12.7 & 7.9 & 4.0 \\
\hline Imports of goods and hontator services & 11.9 & 10.4 & 8.2 & 6.1 & 2.6 & 31 \\
\hline Industrial production index & 1.0 & 3.7 & -0.5 & 6.2 & 2.9 & $\cdots$ \\
\hline Gros domestic invesment (in percent of GDP) 1 & 24.5 & 25,5 & 28.4 & 27.8 & 25.3 & 25.2 \\
\hline Gross national saving (in percent of GDP) & 24.1 & 24. B & 24.5 & 24.4 & 24.9 & 24.9 \\
\hline \multicolumn{7}{|l|}{ Buploynent and Unemploynent } \\
\hline Labor force (in thousands) & 869 & 871 & 877 & 875 & 881 & 875 \\
\hline Employment rate (in percent) & 85.6 & 85.5 & 86.4 & 87.7 & $8 g .4$ & 88.1 \\
\hline \multicolumn{7}{|l|}{ Untent loyment rats (in percent) } \\
\hline Registered umemployed & 14.4 & 14.5 & 33.6 & L2.2 & 11,6 & 11.9 \\
\hline Anmual survey (ILo definition) & 7.4 & 7.9 & 7.6 & 7.0 & 6.4 & 6.7 \\
\hline \multicolumn{7}{|l|}{ Pricese and Incomer } \\
\hline Consurner privea (pervestage change, and-perled) & 8.8 & 6.5 & 8.0 & 8.9 & 7.0 & 5.8 \\
\hline Cohsuner prich (percealinge changs, period arotage) & B.A & 8.0 & 6.1 & 8.9 & B.4 & 6.5 \\
\hline Tenne of trade $(1999-100)\}$ & 101.0 & 103.2 & 103.9 & 98.6 & 99.2 & 99.3 \\
\hline Real gross wagea (percentage change, average) & 3.2 & 1.6 & 3.3 & 1.7 & 3.2 & $\cdots$ \\
\hline \multicolumn{7}{|l|}{ Gonerul Government Fimanesa $2 J$} \\
\hline Revenue & 42.1 & 43.0 & 43.6 & 42.8 & 43.2 & $42: 63$ \\
\hline Expenditure & 43.2 & 43.6 & 44.2 & 44.1 & 44.6 & 45.2 \\
\hline Gematal balances & -1.1 & -0.6 & -0.6 & -1.4 & -1.3 & -2.6 \\
\hline Niet lendäng 4 f & 0.0 & -0.1 & 0.0 & -0.1 & -0.3 & -0.1 \\
\hline Orerall balance of & -1.2 & -0.5 & -0.7 & -1.2 & -1.0 & -2.5 \\
\hline Overall bahace excludiag privatization receipts & -1.7 & -0.9 & 0.9 & $-1,4$ & $-\$ .6$ & -2.9 \\
\hline Deht $5 /$ & 23.2 & 23.7 & 24.5 & 25.1 & 25.30 & 26.0 \\
\hline \multicolumn{7}{|l|}{ Maney and Crablit } \\
\hline Broad money (inc, foreign exchange deposits) & 23.8 & 20.9 & 15.1 & 15.3 & 30.4 & $12-18$ \\
\hline Reserve money & 18.4 & 27.9 & 16.4 & 1.3 & 18.4 & $\ldots$ \\
\hline Credit to the private aector (resl; and of period) & 4.7 & 193 & 17.8 & 8.7 & 9.3 & $\cdots$ \\
\hline Nemmal ínteatank in tereat rete (percent, oremight) & 9.6 & 7.4 & 6.8 & 6.8 & 6.7 & $\cdots$ \\
\hline Lending rates (percenl) & $16-17$ & 12.13 & $12-14$ & 15.8-17.7 & $15.1 \cdot 17.1$ & $\cdots$ \\
\hline Ieposwil rater (porctur) & 7.10 & 47 & 7.10 & $10-14$ & $9.8-13.7$ & $\ldots$ \\
\hline \multicolumn{7}{|l|}{ External Sector } \\
\hline Trede balance & -776 & .789 & $-1,245$ & -1.139 & -622 & -634 \\
\hline (in percen 1 of GDP) & -43 & -4.0 & -6.2 & -6.3 & -3.3 & .3 .1 \\
\hline Current account & 11 & -147 & -783 & $-61]$ & -67 & -69 \\
\hline (in pertenl of (TDP) & 0.1 & -0.8 & .3 .9 & $-9,4$ & -0.4 & -0.3 \\
\hline Capital and financiai accoun! & 1,197 & 244 & 675 & 743 & $1,30 \mathrm{~s}$ & 651 \\
\hline (in percent of GDP) & 6.6 & 1.2 & 3.4 & 4.1 & 7.0 & 3.2 \\
\hline Grogs officist nemoryes of the Bank of Sloweniz $7 /$ & 5,515 & 3,639 & 3,168 & 3,196 & 4,397 & 4,830 \\
\hline (in monthe of importh of goods and arvices) & 3.8 & 3.8 & 3,3 & $\$ .4$ & 4.5 & 5.0 \\
\hline Exaremat debt & 4,1 ? & 4,915 & 5,400 & 6.217 & 6,217 & 6,997 \\
\hline (in percent of exports of guads and services) & 39.4 & 44.2 & S1.3 & 58.1 & 595 & $\ldots$ \\
\hline Of whideh: Public (percent of total) & 48.8 & 47.3 & 45,4 & 42.9 & 403 & $\ldots$ \\
\hline Externad debt sprvice & 921 & 1536 & 846 & 1,034 & 1,656 & 1,386 \\
\hline (in percant of exports of goods and acrvices) & 8.8 & 13.8 & 8.0 & 9.7 & 14.7 & $\cdots$ \\
\hline \multicolumn{7}{|l|}{ Exchange ratas } \\
\hline Tolars per U.S doltar (end-petiod) & 169.2 & 1612 & 196.8 & 227.4 & 250.9 & $\cdots$ \\
\hline Tolars per curo (ond-poriod) & $\cdots$ & $\ldots$ & 197.3 & 211.5 & 221.4 & ... \\
\hline Nocrimal effectipe exchange rate (1995-100, avg.) & 85.4 & 83.2 & 78.0 & $7 ! .5$ & 66.1 & $\ldots$ \\
\hline Real effective excharge rate (CPI haped, 1945-100, avg.) & 57.8 & 100.8 & 900.0 & 97.6 & 97.7 & $\ldots$ \\
\hline
\end{tabular}

Sources: Slovene authorities; and Fwhd affe calculations and projecliens.

I/ Dats for 2001 are the averago for the first threo anartort.

$2 /$ Budgat numbers for 20002.

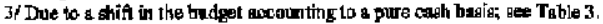

4 Official statisties: inclad privatization revenues is net lending

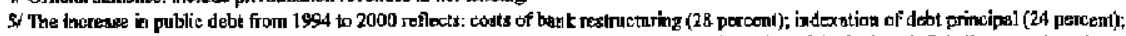

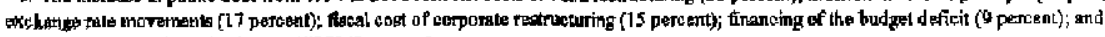

assiumplion of debl from the formex STRY (5 porsott).

6) Debt in Soptember 30, 200: ag 2 share of projected romiris ODP for 2001.

$\gamma /$ Exchudea gold, SDRs, and IMF pogition 
Table 2. Slovenia: Balance of Payments, 1997-2002

$\begin{array}{lllll}1997 & 1998 & 1999 & 2000 & 2001\end{array}$

2002

Proj.

\begin{tabular}{|c|c|c|c|c|c|c|}
\hline Current Account & 11 & -147 & -783 & -611 & -67 & -69 \\
\hline Trade Bajance & -776 & -789 & $-1,245$ & $-1,139$ & -622 & -634 \\
\hline Exports f.o.b. & 8,407 & 9,091 & 8,623 & 8,808 & 9,342 & 9,574 \\
\hline Imports fo.b. & $-9,184$ & $-9,880$ & $-9,868$ & $-9,947$ & $-5,964$ & $-10,208$ \\
\hline Services & 630 & 492 & 364 & 436 & $50 !$ & 499 \\
\hline Exports & 2,047 & 2,027 & 1,899 & 1,886 & 1,946 & 1,972 \\
\hline Of which : Tourism & 1,187 & 1,088 & 954 & 961 & 977 & 996 \\
\hline Imports & $-1,417$ & $-1,535$ & $-I, 535$ & $-1,450$ & $-1,445$ & $-1,473$ \\
\hline Income, net & 39 & 28 & -24 & -25 & -75 & -65 \\
\hline Current transfers, net & 118 & 122 & 123 & 116 & 128 & 131 \\
\hline Capital account & 1 & -1 & -1 & $A$ & -4 & -4 \\
\hline Finnancial account & 1,197 & 244 & 675 & 743 & 1,308 & 556 \\
\hline Direct investment, net & 340 & 250 & 143 & 110 & 338 & 430 \\
\hline In Slovenia & 375 & 248 & 181 & 176 & 442 & 530 \\
\hline Abroad & -36 & 2 & -38 & -66 & -104 & -100 \\
\hline Portfolio investrnent, net & 236 & 90 & 354 & 189 & 89 & 130 \\
\hline Other investment, net & 622 & .95 & 178 & 445 & 881 & -4 \\
\hline Government & .23 & -22 & 17 & 129 & -9 & -110 \\
\hline Bank of Slovenia & -8 & -5 & -6 & -6 & -6 & -6 \\
\hline Commercial banks & 464 & -12 & 251 & 25 & -179 & 112 \\
\hline Nonbank private sector & .89 & -56 & -85 & 298 & 1,074 & 0 \\
\hline Of which : Trade credits & -342 & -429 & -336 & -179 & -210 & -315 \\
\hline Net errors and omissions & 77 & 62 & 27 & 43 & 47 & 0 \\
\hline$\cdot$ & & & & & & \\
\hline Overall balance & 1,287 & 158 & -81 & 178 & 1,285 & 483 \\
\hline Change in official reserves (-: increase) & $-1,287$ & -158 & 81 & -178 & $-1,285$ & 4.83 \\
\hline \multicolumn{7}{|l|}{ Memorandum items } \\
\hline Trade balance & -4.3 & -4.0 & -6.2 & -6.3 & -3.3 & -3.1 \\
\hline Current account balance & 0.1 & -0.8 & -3.9 & -3.4 & -0.4 & -0.3 \\
\hline Capital and financial account & 6.6 & 1.2 & 3.4 & 4.1 & 7.0 & 2.7 \\
\hline External debt & 22.9 & 25.1 & 26.9 & 34.3 & 36.1 & 34.7 \\
\hline (in millions of U.S. dollars) & 4,176 & 4,915 & 5,400 & 6,217 & 6.717 & 6,997 \\
\hline Debt service costs (in millions of U.S. dollars) & 921 & 1,536 & 846 & 1,034 & 1,656 & 1,386 \\
\hline (as percent of exports of G\&NFS) & 8.8 & 13.8 & 8.0 & 9.7 & 14.7 & 12.0 \\
\hline Official reserves (in millions of U.S. dollars) & 3,315 & 3,639 & 3,168 & 3,196 & 4,397 & 4,880 \\
\hline Change in official reserves & 7.1 & 0.8 & -0.4 & 1.0 & 6.9 & 2.4 \\
\hline Gross domestic product (in millions of U.S. dollars) & 18,202 & 19,585 & 20,071 & 18,122 & 18,630 & 20,154 \\
\hline
\end{tabular}

Soures: Bank of Slovenia; and Fund steff calculiations. 
Table 3. Slovenia: Summary of General Government Operations (In percent of GDP)

\begin{tabular}{|c|c|c|c|c|c|c|}
\hline & 1997 & 1998 & 1999 & 2000 & $\frac{2001}{\text { Prelim. }}$ & $\frac{2002}{\text { Budget }}$ \\
\hline TOTAL, REVENUE & 42.1 & 43.0 & 43.6 & 42.8 & 43.2 & 42.62 \\
\hline Tax reyenue & 39.8 & 40.0 & 41.1 & 39.6 & 39.5 & 39.2 \\
\hline Personal income tax & 6.7 & 6.6 & 6.3 & 6.4 & 6.4 & 6.6 \\
\hline Corperate income tax & 1.2 & 1.2 & 1.2 & 1.3 & 1.5 & 1.6 \\
\hline Social security contributions and payroll taxes & 15.1 & 15.2 & 15.1 & 15.4 & 15.5 & 159 \\
\hline Domestic taxes on goods and services & 14.2 & 14.7 & 16.5 & 14.9 & 14.8 & 13.9 \\
\hline Ofwhich: VAT & 0.0 & 0.0 & 5.7 & 9.9 & 9.7 & 9.0 \\
\hline Excise taxes & 0.0 & 0.0 & 1.9 & 3,3 & 3.7 & 3.4 \\
\hline Taxes on ittemational trade & 2.7 & 2.3 & 2.0 & 1.6 & 1.4 & 1.2 \\
\hline Nontax revenue & 2.1 & 2.7 & 2.2 & 2.7 & 3.1 & 2.6 \\
\hline Capjtal revenus and grants & 0.1 & 0.1 & 0.3 & 0.4 & 0.7 & 0.8 \\
\hline TOTAL EXPENDITURE & 43.2 & 43.6 & 44.2 & 44.1 & 44.6 & 45.2 \\
\hline Curient expendirure & 19.4 & 19.4 & 19.1 & 19.4 & 20.1 & 20.5 \\
\hline Salaries and wages & 9.8 & 9.6 & 9.6 & 9.6 & 100 & 10.2 \\
\hline Expenditures on goods and services & 8.4 & 8.5 & 8.1 & 8,3 & 8.4 & 8.6 \\
\hline Incerest payments & 1.2 & 1.3 & 1.4 & 1.5 & 1.6 & 1.7 \\
\hline Current transfers & 19.7 & 19.9 & 20.5 & 20.5 & 20.0 & 20.4 \\
\hline Transfers to individuals and households & 5.7 & 5.6 & 5.7 & 6.0 & 6.0 & 6.1 \\
\hline Pensions & 12.1 & 12.0 & 12.1 & 12.2 & 12.0 & 11.9 \\
\hline Subsidies & 1.4 & 1.5 & 1.7 & 1.5 & 1.4 & 1.4 \\
\hline Other transfers & 0.4 & 0.4 & 1.0 & 0.9 & 0.6 & 0.9 \\
\hline Capital expenditure and transfers & 4.2 & 4.3 & 4.6 & 4.2 & 4.5 & 4.3 \\
\hline GENERAL BALANCE & $-1,1$ & -0.6 & .0 .6 & -1.4 & $-1,3$ & -2.627 \\
\hline Net lending & 0.0 & 0.1 & 0.0 & 0.1 & 0.3 & -0.1 \\
\hline Lending minus repayments & 0.6 & 0.3 & 0.3 & 0.0 & 0.3 & -0.1 \\
\hline Revenues from privatization & 0.5 & 0.4 & 0.3 & 0.1 & 0.6 & 0.5 \\
\hline DVERALL BALANCE & -1.2 & -0.5 & -0.7 & -1.2 & -1.0 & -2.8 \\
\hline FINANCING (NET) & 1.2 & 0.5 & 0.7 & 1.2 & 1.0 & 2.8 \\
\hline Total borrowing & 1.1 & 1.1 & 1.2 & 1.3 & 1.6 & 2.8 \\
\hline Foreign borrowing (net) & 0,7 & 0.3 & 1.7 & 1.7 & 0.5 & -0.5 \\
\hline Domestic bortowing (net) & 0.4 & 0.7 & -0.5 & -0.5 & 1.1 & 3.3 \\
\hline Changes in cash deposits (increase $=+$ ) & -0.1 & 0.4 & 0.5 & 0.0 & 0.6 & 0.0 \\
\hline
\end{tabular}

1/ The VAT was introduced in July 1999.

2/ The budget accounting will be shifted onto pure cash basis in 2002. VAT and excise tax revenues acerued in December but coilected in January, which had been secorded in the preceding year until 2002 , wil] be recorded when collected. Therefore 2002 will have 11 months of VAT and excise tax revenues instead of 12 months, a difference of about 1.5 percent of GDP. 
Table 4. Slovenia: Stafi's Medium-Term Macroeconomic Scenario, 1998-2006

\begin{tabular}{|c|c|c|c|c|c|c|c|c|c|}
\hline & \multirow[b]{2}{*}{1998} & \multirow[b]{2}{*}{1999} & \multirow[b]{2}{*}{2000} & \multirow{2}{*}{$\frac{\text { Est }_{1}}{2001}$} & \multicolumn{5}{|c|}{ Proj. } \\
\hline & & & & & 2002 & 2003 & 2004 & 2005 & 2006 \\
\hline & \multicolumn{9}{|c|}{ (Real growth rate) } \\
\hline Real GDP & 3.8 & 5.2 & 4.6 & 3.0 & 2.5 & 3.5 & 4.9 & 5.2 & 5.5 \\
\hline Domestic demand & 3.9 & 5.6 & 1.4 & 0.1 & 2.1 & 3.1 & 4.1 & 4.6 & 4.7 \\
\hline Private consumption & 3.3 & 6.0 & 0.8 & 1.5 & 1.9 & 3.8 & 3.9 & 4.8 & 5.0 \\
\hline Public consumption & 5.8 & 4.6 & 3.1 & 3.5 & 3.4 & 0.8 & 3.2 & 3.4 & 3.5 \\
\hline Investment & 12.4 & 18.9 & 0.8 & -50 & 1.4 & 3.7 & 4.6 & 5.1 & 4.9 \\
\hline Exports GNFS & 6.7 & 1.7 & 12.7 & 7.1 & 4.0 & 4.7 & 5.3 & 5.3 & 5.6 \\
\hline Imports GNFS & 10.4 & 8.2 & 6.1 & 2.3 & 3.3 & 4.2 & 4.1 & 4.4 & 4.4 \\
\hline \multirow[t]{2}{*}{ Consumer price inflation (average) } & 7.9 & 6.2 & 8.9 & 8.5 & 6.5 & 5.5 & 4.5 & 4.0 & 3.5 \\
\hline & \multicolumn{9}{|c|}{ (Percent of GDP) } \\
\hline \multicolumn{10}{|l|}{ Public finance } \\
\hline Government revenue & 43.0 & 43.6 & 42.8 & 43.2 & $42.1 \mathrm{H}$ & 42.6 & 42.6 & 42.7 & 42.8 \\
\hline Governitent expenditure $Z$ & 43.8 & 44.2 & 44.1 & 44.6 & 44.7 & 44.2 & 43.7 & 42.5 & 42.0 \\
\hline Overall balance (exciuding privatization receipts) & -0.9 & 0.9 & .1 .2 & -1.4 & -2.6 & -1.6 & -1.1 & 0.2 & 0.8 \\
\hline General government debt & 23.8 & 24.7 & 25.1 & 25.3 & 26.5 & 26.3 & 24.3 & 21.2 & 19.0 \\
\hline \multicolumn{10}{|l|}{ Balance of payments } \\
\hline Trade balance & $-4,0$ & -6.2 & -6.3 & -3.3 & -3.1 & -3.2 & -2.7 & -2.4 & .2 .0 \\
\hline Current account balance & -0.8 & -3.9 & -34 & -0.4 & -0.3 & $-0,4$ & -0.3 & -0.4 & -0.4 \\
\hline
\end{tabular}

Source: Fund staff projections.

1/ Due to a shift in the budget actounting to a pure cash basis, see 'Table 3 .

2/ The expenditure path during 2002-05 includes the recessary expenditure adjustrient to achieve the authorities medium-ierm objectives. 
Table 5. Slovenia: Vulnerability Indicators, 1995-2001

(In percent of GDP, unless otherwise indicated)

\begin{tabular}{llllllll}
1995 & 1996 & 1997 & 1998 & 1999 & 2000 & 2001 & Latest \\
\hline Date
\end{tabular}

\section{Financial Indicators}

Public sector debt

Broad money (percent change, 12 -month basis)

Privale sector credit, real (percent change, 12-month basis)

Domestic credit

Foreign exchange deposits (percent of broad tnoney)

Banks' ronperforming assets (percent of total assets)

Banks' bad assets (percent of total assets)

Capitsl adequacy ratio

\section{External Indicators}

Exports G\&NFS (percent change, 12-month besis in USS)

Inipotts G\&NFS (petcert change, 12-month basis in US\$)

Current accoumt balance

Capital and financial account balknce

Of which : Inward portfolio investment

Inward foreign direct investment

Other investment, net

Net foreiga assets of commencial backs (US\$ billions)

Gross officiat reserves (US\$ billions) I/

Net international reserves (US 5 billions) $2 /$

Short-term foreign assets of cormmercial banks (US\$ billions)

Stort-term foreign liabilities of commetcial berks (US\$ biltions)

Foreign cunency expasure of commercial barks (USS billions)

Official reserves in months of imports G\&NFS

Base money to gross official reserves (percentage)

Broad mortey to gross official reserves (percentage)

Short-term external debt to gross official reserves (percentage) 3 /

Short-term extemal debt to gross official reserves (percentage) 41

Total extempal debt

Of which : Public sector debt

Tot:al external debt to exports G\&NFS (perceutage)

Total external debt service payments to expons. G\&NFS

External interest payments to exports G\&NFS

External anortization payments to exports G\&NFS

Exchange rate (per USS, period average)

REER appreciation $(+)$ (period-awerage basis, CPI-based)

$\begin{array}{rr}18.8 & 22.7 \\ 32.3 & 20.5 \\ 26.4 & 9.0 \\ 42.2 & 41.5 \\ 34.5 & 33.9 \\ 5.8 & 6.4 \\ 4.0 & 4.0 \\ 21.5 & 20.0\end{array}$

23.2
24.3
4.7
41.7
28.7
5.6
3.3
18.3

\section{7}

19.8

19.3

45.6

25.3

5.7

3.7

16.0

\section{4,5}

13.2

17.8

48.5

26.0

5.8

3.5

14.0

\begin{tabular}{|c|c|c|c|c|c|c|c|}
\hline 20.1 & l.1 & -0.3 & 6.3 & -5.4 & 1.6 & 5.5 & December-ôf \\
\hline 29.0 & -0.7 & -0.7 & 7.7 & -0.1 & -0.1 & 0.1 & December-at \\
\hline-0.5 & 0.2 & 0.1 & -0.8 & -3.9 & -3.4 & -0.4 & Detember-al \\
\hline 2.8 & 3.0 & 6.6 & 1.2 & 3.4 & 4.1 & 7.0 & December-0I \\
\hline 0.1 & 3.3 & 1,3 & 0.6 & 1.8 & 1.4 & 0.5 & Deseinbern- $\theta$ t \\
\hline 0.9 & 1.0 & 2.1 & 1.3 & 0.9 & 1.0 & 1.8 & Decembey-Q] \\
\hline 2.0 & -1.4 & 3.4 & -0.5 & 0.9 & 2.5 & 4.7 & December-01 \\
\hline 0.9 & 1.1 & 0.6 & 0.7 & 0.4 & 0.4 & 1.5 & Decrmber-ol \\
\hline 1.8 & 2.3 & 3.3 & 3.6 & 3.2 & 3.2 & 4.4 & Decenser $\sim 0 I$ \\
\hline 1.3 & 1.8 & 2.7 & 3.0 & 2.5 & 2.4 & 3.5 & December-0I \\
\hline 1.9 & 2.0 & 1.3 & 1.4 & 1.3 & 1.4 & $\cdots$ & Decentber-do \\
\hline 0.2 & 0.4 & 0.3 & 0.4 & 0.4 & 0.4 & $\ldots$ & December-DO \\
\hline-0.7 & -1.2 & -1.4 & -1.3 & -1.3 & -1.4 & +0.8 & December-al \\
\hline 2.0 & 2.6 & 3.8 & 3.8 & 3.3 & 3.4 & 4.6 & December-01 \\
\hline 43.2 & 35.2 & 25.1 & 28.6 & 32.7 & 28.4 & 25.7 & December-as \\
\hline 411 & 349 & 252 & 288 & 307 & 304 & 264 & December-af \\
\hline$\ldots$ & 2.1 & 4.J & 3.0 & 3.7 & 3.1 & 2.9 & Decentber-as \\
\hline$\cdots$ & $\cdots$ & $\ldots$ & $\cdots$ & $\ldots$ & $\ldots$ & 32.3 & December-al \\
\hline$\ldots$ & 21.1 & 22.6 & 25.1 & 26.9 & 34.3 & 36.0 & December-al \\
\hline$\ldots$ & 10.6 & I1.1 & il. .9 & 12.2 & [4.7 & 14.5 & December-al \\
\hline ... & 38.0 & 39.4 & 44.2 & 51.3 & 58.1 & 59.5 & December- $\theta 1$ \\
\hline ... & 8.8 & 8.8 & 13.5 & 8.0 & 9.5 & 14.7 & December-OJ \\
\hline ... & 1.8 & 2.1 & 2.1 & 2.3 & 2.8 & 3.2 & Detembot-DJ \\
\hline$\ldots$ & 7.0 & 6.6 & II.5 & 5.7 & 6.7 & 11.5 & December-ol \\
\hline 118.5 & 135.4 & 159.7 & 166.1 & 181.8 & 222.7 & 242.8 & Decambor-dI \\
\hline 10.9 & -3.3 & 0.3 & 3.8 & -0.7 & -2.5 & 0.2 & Decemb̀st-1] \\
\hline 1,449 & 1,183 & 1,405 & 1,706 & 1,806 & 1,808 & 2152 & December-01 \\
\hline 4.5 & 6.9 & 13.7 & 21.8 & 2.5 .2 & 28.2 & 30.5 & Decenter-0I \\
\hline$\cdots$ & $\ldots$ & A & A & A & A & A & $J A H u a r y=02$ \\
\hline$\cdots$ & $\cdots$ & 65 & 71 & 71 & 60 & 43 & Denember-01 \\
\hline
\end{tabular}

25.4 September-ald

30.4 Decomber 01

9.3 Decembereal

53.3 December-01

32.1 December-[1]

5.2 hune-01

3.3 Jing-0I

13.5 June-0.1

\section{Financlal Market Indicators (end of period) \\ Stock market index \\ Stock market capitalization \\ Foraign ctrrency debt tating ( $\$ \& P$, long term) \\ Spread of betchmatk bond (basis points) $5 /$}

)

Sources: Bank of Slovenia; Statistical Office of the Republic of Slovenia, Ministry of Finance; Bloomberg; and Fund staff calculations.

1/ Inchudes foreign exchange, gold, SDRs, and reserve position in the Fund.

2/ Excludes sever-day foreign currency repurchase agreements with domestic banks amounting to US\$ 1.1 billion.

3/ Shott-term debt on original maturity basis.

4/ Short-term debt on remaining matuxity basis.

5/ Yield differential on a seven-year DEM-denominated Slovene govemment bond, maturing in 2004. 


\section{SLOVENia: Fund RELations \\ (As of January 31, 2002)}

I. Membership Status: Joined: 12/14/1992; Article VIII status as from September 1, 1995.

II. General Resources Account:

SDR Million

231.70

167.54

64.16

18.00

(net)

SDR Department:

III.

Net cumulative allocation

Holdings

Designation Plan
SDR Million

25.43

4.00

0.00
\%Quota

100.00

72.31

27.69

…

\%Allocation

100.00

15.74

IV. Outstanding Purchases and Loans: None

V. Financial Arrangements: None

VI. Projected Obligations to Fund: None

VII. Exchange Rate Arrangement

The currency of Slovenia is the tolar (SIT). Slovenia maintains a managed floating exchange rate. The exchange rate of the tolar for transactions by legal entities is determined in the interbank market, in which the Bank of Slovenia $(\mathrm{BoS})$ is a major participant. Like any other market participant, the BoS buys and sells foreign exchange at the market-determined exchange rate. On December 30, 2001, the middle rate for spot transactions in the interbank market was SIT $250.9=$ US\$1.

\section{Last Article IV Consultation}

The last Article IV consultation was concluded on May 11, 2001 on the basis of SM/01/113, (April 19, 2001). It was agreed that Slovenia would remain on the standard 12-month cycle. The Acting Chairman's summing up of the discussion was circulated as SUR/01/54. 


\section{FSAP Participation and ROSCs}

An FSAP mission took place during November 6-20, 2000, and follow-up meetings were held with the authorities on February 8-9, 2001 in the context of the 2001 Article TV consultation mission. An FSSA report (SM/01/129) was prepared on April 24, 2001 and published on September 18, 2001 (Country Report No. 01/161). The report includes assessments of the following standards: banking supervision, securities regulation, insurance regulation, and payments systems.

A final document of the fiscal transparency $\mathrm{ROSC}$, incorporating the authorities' comments obtained during the December 2002 Article IV consultation mission is circulated as an accompanying document to this report.

\section{Technical Assistance}

\section{Date}

October 1992

December 1991

April-May 1993

July 1993

September 1993

July 1994

February 1995

January-February 1995

March 1995

April 1995

May 1995

June 1995

September-October 1995

November-December 1995

December 1996

December 1996

February-March 1997

May 1997

September 1997

November 1997

January 1998

April 1998
Dept.

FAD

STA

FAD

FAD

STA

STA

LEG

FAD

STA

MAE

MAE

LEG

FAD

STA

FAD

FAD

FAD

STA

STA

STA

FAD

FAD

\section{Subject/Identified Need}

Tax Reform Strategy

Balance of Payments

Tax Administration

Tax Policy

Money and Banking

Money and Banking

Foreign Exchange Law

Public Expenditure Management

Balance of Payments

Deindexation of Financial Assets

Seminar on Monetary Policy

Income Tax Law

Social Insurance System

National Accounts

Tax Policy

Public Expenditure Management

Treasury Single Account and

Ledger Accounting System

National Accounts

Money and Banking

Government Finance

GFS Based Budget and Accounting Classification

GFS Based Budget and Accounting Classification 
July 1998

September 1998

November 1998

December 1998

March 1999

March 1999

April 1999

October 1999

November 2000

August 2001

November 2001
FAD

FAD

FAD

STA

FAD

FAD

FAD

STA

MAE

FAD

FAD
Public Expenditure Management and Treasury Single Account Public Expenditure Management Public Expenditure Management Flow-of-Fund and Financial Programming

Public Expenditure Management (ends 6/00)

Fiscal Management

Tax Administration/VAT

Government Finance Statistics

FSAP

VAT

Direct Tax Reform 


\section{Slovenia: Review of Statistical Issues}

Special Data Dissemination Standards: Slovenia has subscribed to the Special Data Dissemination Standard (SDDS), meets the SDDS specifications, and its metadata are posted on the Fund's Dissemination Standards Bulletin Board on the Internet.

Real Sector Statisties: The Statistical Office (SO) follows primarily the European System of Accounts 1995 . Quarterly GDP estimates by industry and expenditure categories are compiled at both current and constant 1995 prices, and are regularly published within 80 days after the reference quarter. The SO has addressed most recommendations of a 1997 STA mission.

As regards consumer and producer prices, the indices are compiled in accordance with international standards. The $\mathrm{SO}$ also compiles a retail price index (RPI), which differs from the consumer price index in weights only. As suggested by the national accounts mission, the SO has plans to discontinue the compilation of the RPI.

Government Finance Statistics: Slovenian fiscal statistics are timely and of a high quality. The MoF publishes a monthly Bulletin of Government Finance, which presents data on the operations of the central and local governments, the social security funds, and the consolidated general government. The coverage of general government excludes the operations of extrabudgetary funds and own revenues of general government zavods. However, these operations are not statistically significant. Monthly fiscal indicators are reported for publication in $I F S$ on a timely basis. The latest data published in the GFS Yearbook are budget estimates for 2001.

Money and Banking Statistics: Monetary statistics are timely and of good quality. Recently, the authorities requested advice on the treatment of subordinated debt in the monetary aggregates, and immediately took steps to implement STA's recommendations.

Balance of Payments Statistics: At present, balance of payments data for Slovenia are comprehensive and of high quality, and have been published in the Balance of Payments Statistics Yearbook since 1993 (with estimates of the international investment position published since 1994). 
Slovenia: Survey of Reporting of Main Statistical Indicators

(as of January 31, 2002)

\begin{tabular}{|c|c|c|c|c|c|c|c|c|c|c|c|c|}
\hline & $\begin{array}{c}\text { Exchange } \\
\text { rates }\end{array}$ & $\begin{array}{l}\text { International } \\
\text { reserves }\end{array}$ & $\begin{array}{c}\text { Reserve/ } \\
\text { base } \\
\text { money }\end{array}$ & $\begin{array}{c}\text { Central } \\
\text { Bank } \\
\text { balance } \\
\text { sheet }\end{array}$ & $\begin{array}{l}\text { Broad } \\
\text { money }\end{array}$ & $\begin{array}{l}\text { Interest } \\
\text { rates }\end{array}$ & $\begin{array}{c}\text { Consumer } \\
\text { price } \\
\text { index }\end{array}$ & $\begin{array}{l}\text { Exports/ } \\
\text { imports }\end{array}$ & $\begin{array}{l}\text { Current } \\
\text { account } \\
\text { balance }\end{array}$ & $\begin{array}{c}\text { Central } \\
\text { government } \\
\text { balance }\end{array}$ & GDP/GNP & $\begin{array}{c}\text { External } \\
\text { debt }\end{array}$ \\
\hline $\begin{array}{l}\text { Date of latest } \\
\text { observation }\end{array}$ & Jan. 31,02 & Dec-0I & Dec-01 & Dec-01 & Dec-01 & Dec-01 & Dec-01 & Nov-01 & Nov-01 & Nov-01 & Q3-01 & Nov-01 \\
\hline Date received & Jan. 31,02 & Jan-02 & Jan-02 & Jan. 16,02 & Jan-02 & Jan-02 & Dec. 31,01 & $\operatorname{Jan} 11,02$ & $\operatorname{Jan} 15,02$ & Jan-02 & Dec-0I & Jan- 02 \\
\hline Frequency of data & Daily & Monthly & Monthly & Monthly & Monthly & Monthly & Monthly & Monthly & Monthly & Monthly & Quarterly & Monthly \\
\hline $\begin{array}{l}\text { Frequency of } \\
\text { reporting/ } \\
\text { publication }\end{array}$ & $\begin{array}{l}\text { Daily/ } \\
\text { Daily }\end{array}$ & $\begin{array}{l}\text { Monthlyi } \\
\text { Monthly }\end{array}$ & $\begin{array}{l}\text { Monthly/ } \\
\text { Monthly }\end{array}$ & $\begin{array}{l}\text { Monthly/ } \\
\text { Monthly }\end{array}$ & $\begin{array}{l}\text { Monthly/ } \\
\text { Monthly }\end{array}$ & $\begin{array}{l}\text { Monthly/ } \\
\text { Monthly }\end{array}$ & $\begin{array}{l}\text { Monthly/ } \\
\text { Monthly }\end{array}$ & $\begin{array}{l}\text { Monthly/ } \\
\text { Monthly }\end{array}$ & $\begin{array}{l}\text { Monthly/ } \\
\text { Monthly }\end{array}$ & $\begin{array}{l}\text { Monthly/ } \\
\text { Monthly }\end{array}$ & $\begin{array}{l}\text { Quarterly/ } \\
\text { Quarterly }\end{array}$ & $\begin{array}{l}\text { Monthlyf } \\
\text { Monthly }\end{array}$ \\
\hline Source of data & BoS & BoS & $\mathrm{BoS}$ & BoS & BoS & BoS & $\begin{array}{c}\text { BoS/ } \\
\text { NSO/ } \\
\text { Reuters }\end{array}$ & $\begin{array}{c}\text { BoS/ } \\
\text { NSO/ } \\
\text { Reuters }\end{array}$ & $\begin{array}{c}\text { BoS/ } \\
\text { Reuters }\end{array}$ & $\mathrm{MoF}$ & NSO & Bos \\
\hline $\begin{array}{l}\text { Mode of } \\
\text { reporting }\end{array}$ & On-line & $\begin{array}{c}\text { On-line/ } \\
\text { E-Mail }\end{array}$ & $\begin{array}{l}\text { On-line' } \\
\text { E-Mail }\end{array}$ & $\begin{array}{l}\text { On-linef } \\
\text { E-Mail }\end{array}$ & $\begin{array}{l}\text { On-line/ } \\
\text { E-Mail }\end{array}$ & $\begin{array}{c}\text { On-line } \\
\text { E-Mail }\end{array}$ & $\begin{array}{c}\text { On-line' } \\
\text { E-Mail } \\
\end{array}$ & $\begin{array}{c}\text { On-line/ } \\
\text { E-Mail }\end{array}$ & $\begin{array}{c}\text { On-line } \\
\text { E-Mail }\end{array}$ & $\begin{array}{c}\text { On-line/ } \\
\text { E-Mail }\end{array}$ & $\begin{array}{l}\text { On-lined } \\
\text { E-Mail }\end{array}$ & $\begin{array}{c}\text { On-line/ } \\
\text { E-Mail }\end{array}$ \\
\hline Confidentiality & Public & Public & Public & Public & Public & Public & Public & Public & Public & Public & Public & Public \\
\hline
\end{tabular}

Note: BoS, NSO, and MoF stand for Bank of Slovenia, Statistical Office of the Republic of Slovenia, and Ministry of Finance, respectively. 


\section{The Eastward Push of Slovenian Exports: Near-Term Prospects and Medium-Term Implications}

Following independence in 1991 and the attendant loss of markets in the former SFRY, Slovenia deftly re-oriented its trade toward the EU. The share of exports to the EU increased steadily from 61 percent in 1992 to 67 percent in 1995. While the republics of the former SFRY - particularly Croatia - remained an important destination for Slovenian exports, their share in exports fell from 23 percent to 14.5 percent over this period.

Beginning in 2000, and accelerating further in 2001, a renewed expansion of Slovenian exports to southeastern Europe and Russia took place, even as exports to the EU continued to grow. While the expansion covered a broad group of countries, the largest increases in exports were to the former SFRY, Croatia, and Russia. As a result, the share of Slovenian exports to the countries of the former SFRY rose to 17 percent during the first 11 months of 2001, while the EU's share shrank to 63 percent.

Slovenia: Composition of Exports, 1992, 1995, and 2001

(As share of total)

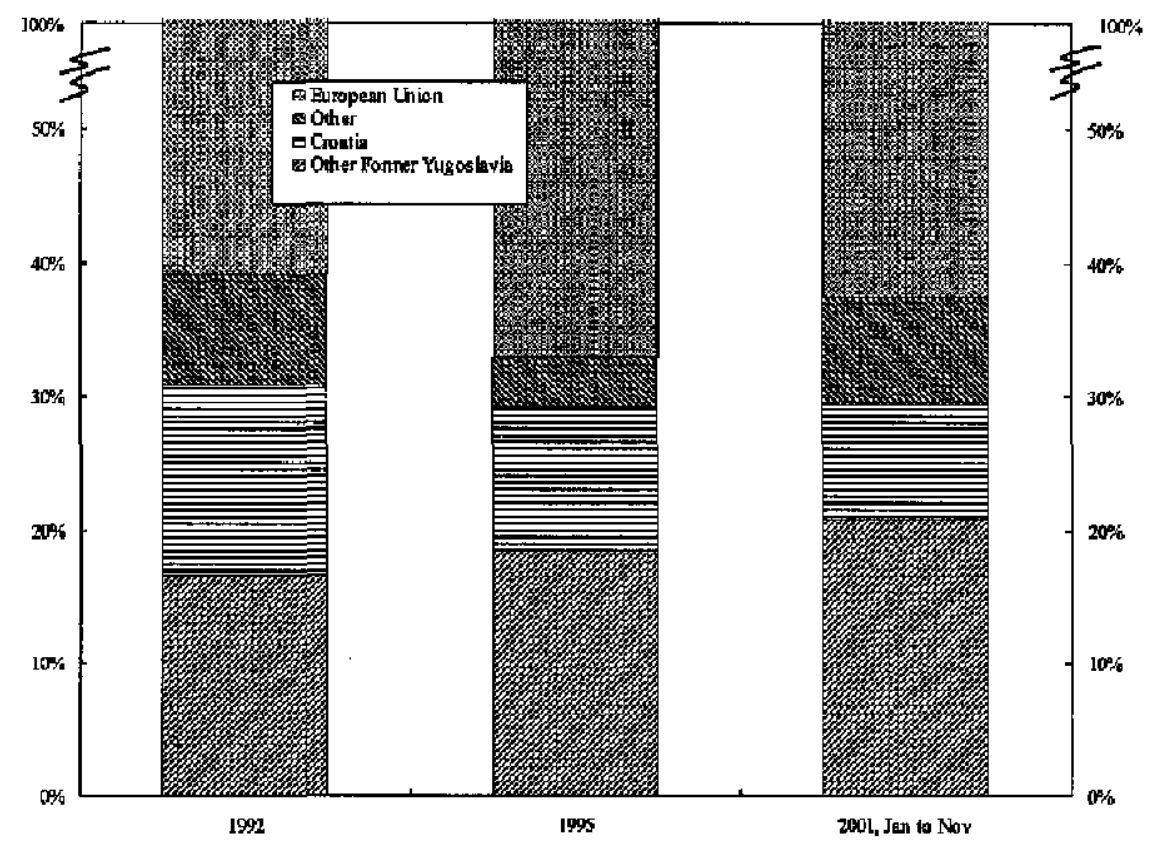

Source: Bank of Slovenia.

The re-orientation of Slovenian exports to the east and, in particular, to the former SFRY, has been driven by a variety of factors. These include improved political and macroeconomic stability in the destination countries, together with knowledge of the language, brand recognition by local consumers, the relative ease with which past business connections have been renewed, and-as regards Croatia - a significant improvement in competitiveness. Moreover, since other foreign countries have not yet established strong footholds in the 
former SFRY, Slovenian firms are well placed to recapture - -at least temporarily-a large share of the market, free from the intense competition they face when exporting to the EU.

However, the potential for further eastward expansion of Slovene exports in the near-term is limited by demand and supply constraints. On the demand side, rapid economic growth is set to continue in former SFRY, but growth in Croatia and Russia is likely to be lower in 2002. On the supply side, exports to southeastern Europe are predominantly consumer goods (including food and white goods), while exports to the EU are mostly intermediate electronic and electrical engineering goods. As a result, the potential for shifting exports across markets-and thus cushioning the impact on total exports of a softening of EU demand-is limited by differences in the types of products demanded. In addition, the increase in exports to these new markets has been financed in part through trade credits provided by Slovene firms. The increase in total trade credits during the first 11 months of 2001 compared with a year earlier was equivalent to 60 percent of the increase in exports to former SFRY and Russia over the same period. With the stock of trade credits exceeding 11 percent of GDP, concerns about the ability to collect payment for exports may lead Slovene firms to slow their expansion to the region in the near term.

Over the longer term, the markets of southeastern Europe will offer substantial growth opportunities for Slovene firms, but the nature of economic ties to these countries can be expected to change. Significantly lower wages in southeastern Europe compared with Slovenia limit long-run export potential to the region and make it more attractive for Slovene firms to invest directly in these countries in order to benefit from their low labor costs. Already, outward FDI to the former SFRY exceeds US $\$ 500$ million (representing 65 percent of outward FDI), largely to acquire companies undergoing privatization in Bosnia and Herzegovina, Croatia, and FYR Macedonia. Economic transformation in the former SFRY and the normalization of diplomatic relations between the two countries will provide further opportunities to participate in the regional privatization process. Offshore production would also allow Slovene-owned firms to penetrate the large markets of Bulgaria and Romania with relatively low-cost goods. Another factor supporting outward FDI as against exporting domestically produced goods is to take advantage of differences in bilateral trade regimes. At the time of EU accession, Slovenia will have to adopt the trade regime of the EU, which imposes zero tariffs on imports from countries of the former SFRY but allows those countries to levy duties on some imports from the EU. In order to avoid these duties on its exports to the countries of the former SFRY, Slovene firms might prefer to locate in these countries.

Shifting from exporting domestically produced goods to investing and producing abroad would have implications for the level and composition of economic activity in Slovenia. Compared to a situation of domestic production and exports, outward investment and production abroad would ceteris paribus decrease the pace of domestic investment and exports, thereby reducing GDP growth. However, national income would exceed GDP by the amount of profit income eamed from foreign investments. 


\section{Progress in Implementing the BoS's Financial Sector Action Plan}

The BoS's Financial Sector Action Plan, prepared in response to the recommendations of the FSAP (SM/01/129 and SM/01/113) was presented in SM/01/113 Box 4. The implementation of the Action Plan has progressed so far according to the set timetable.

\section{Strengthening prudential oversight and risk management}

The capital adequacy requirements were amended as follows.

- The BoS has acquired the right to ask for a capital adequacy ratio of more than the standard 8 percent from a bank, if it is concerned about its risk exposure. Moreover, the overall net foreign exchange position for the capital requirement of a bank is reported on a monthly rather than a quarterly basis, and is calculated based on the gross aggregate method (the overall net position is the sum of net long and short positions).

- The net forward position does not include the forward part of the temporary transaction (purchase or sale) of foreign exchange through the obligatory sale back or buyback effected with the BoS.

In order to improve risk management in banks, the BoS set up a task force to prepare a new decree on market risk management. Moreover, the BoS issued recommendations for credit risk management, and has been checking compliance with these during on-site inspections.

The following steps were undertaken to improve banking sector supervision and ensure the integrity of the banking system.

- The Banking Act was amended to include rules on the exposure of banks to connected parties (connected lending): the provisions allowing granting credits to connected persons under more favourable terms and conditions have been deleted; banks have to notify the supervisory board about any connected exposure in excess of 1 percent of their capital; and a three-year transition period has been given to banks to reduce their exposure to connected lending to below the legal limit.

- Consolidated supervision of banks and bank groups was introduced in 2001.

- A decree was issued defining the precise criteria for meeting the fit-and-proper test for members of a bank's management board or liquidator.

- A new law, giving supervisors the responsibility to detect money-laundering activities, became effective in October 2001. 
- Special monetary awards and other incentives were given to supervisors who achieved exceptional results in 2001.

- The BoS has signed Memoranda of Understanding with supervisory authorities in USA, Austria, Germany, the FYR Macedonia, and Italy. Steps to formalize cooperation with France and Bosnia and Herzegovina are underway.

- The BoS has prepared a draft framework that would formalize and deepen the scope of cooperation between the supervisors and external auditing companies. The draft is currently being discussed with the Slovenian Institute of Auditing.

\section{Improving liquidity management}

The BoS took steps to improve the operation of the money market and enhance the effectiveness of its intervention instruments.

- An agreement with the MoF, signed in 2001, is aimed at developing the money market based on weekly auctions for one-month T-bills. Steps were also taken to establish an over-the-counter secondary market for T-bills in coordination with the Central Clearing House.

- BoS foreign currency bills with maturity in excess of 120 days were discontinued; the maturity of the Lombard facility was shortened from five to one day; 2-day tolar bills were replaced by an overnight deposit facility; the tap for 270-day tolar bills was replaced by auctions; and the treatment of foreign and domestic currency assets in the liquidity ladder was consolidated.

\section{Completing the reform of the payments system}

The following steps were taken to fulfil the requirements set in the Core Principles for Systemically Important Payment Systems.

- A draft Law on Payments Operations, expected to be passed in 2002, stipulates the deadline for the transfer of all accounts from the Agency for Payments.

- A study has been prepared on the implementation of the guarantee scheme for the Giro Clearing system. The guarantee scheme, a loss-sharing agreement backed by $\mathrm{T}$ bills, will be a safeguard against default by net debtors, and is expected to be implemented by July 2002 .

- An agreement with all participating banks on the formation of the National Payment Systems Council is expected to be signed at the beginning of 2002, defining cooperation in payments operations in order to align the Slovene payments system with the international standards. 


\section{The New Monetary Policy Framework}

During the 1990s, extensive restrictions on capital inflows and outflows permitted the $\mathrm{BoS}$ to pursue disinflation while ensuring that the exchange rate of the tolar was on a steady, moderately depreciating path. More recently, preparations for EU entry have engendered major changes to the modus operandi of monetary policy owing to the need to liberalize capital flows and, prospectively, harmonize reserve requirements in Slovenia with the much lower ones in the EU. These changes brought about a sharp increase in the volatility of capital flows (the surplus on the financial account of the balance of payments from 1.2 percent of GDP in 1998 to an estimated 5.5 percent of GDP in 2001) and an attendant loss of control over the targeted broad monetary aggregate M3. In response to these developments, and given the need to ensure a smooth transition to ERM2, in late 2001 the BoS developed a new framework for monetary policy during this interim period.

The new framework establishes the goals and procedures for conducting monetary policy during the period prior to ERM2. The BoS aims to join ERM2 as soon as possible following EU accession, and to remain within the exchange rate mechanism for the minimum required period (two years) before adopting the euro. With EU accession expected in early 2004, and in view of the need to achieve disinflation to euro-area levels by the end of the second year in ERM2, the BoS has therefore set a long-term inflation target of 3-4 percent for 2005, and specific end-year forecasts for end-2002 (5.8 percent) and end-2003 (4.1 percent) consistent with this goal. As nominal convergence is achieved, the BoS expects also to achieve a gradual approximation of the nominal exchange rate to a level that could be suitable as the central parity in ERM2. However, the $\mathrm{BoS}$ is not targeting a specific nominal exchange rate level or path.

During the pre-accession period, the BoS must contend with a number of hurdles that could disrupt the smooth operation of monetary policy. First, interest rate transmission is still unreliable, while the phasing out of interest rate indexation to inflation could bring about changes in the composition of broad money. Second, the elimination of most remaining capital controls will, under conditions of a managed floating exchange rate, further reduce the BoS's control over broad money. Third, the need to reduce gradually the level of reserve requirements in line with ECB regulations will exacerbate the already large surplus structural liquidity position, and could add considerably to the central bank's sterilization costs. And fourth, the development of tolar and foreign-currency interbank markets will alter the interest rate transmission channel. These hurdles, together with the BoS's ambitious disinflation goals, suggest the need for a cautious approach to transforming the monetary framework.

In this environment, the BoS has chosen an eclectic approach (similar to the one used by the ECB), consistent with its view of the primacy of monetary aggregates in determining longrun inflation, wbile also acknowledging the importance of other supplementary indicators. This "two-pillar" system consists of:

- A First Pillar that includes the broad monetary aggregate M3, as well as its individual components. Particular attention is given to M1 because of its close relationship with 
domestic demand and its connection to base money controlled by the BoS. Also included are measures of banks' free reserves, the term structure of interest rates, banks' lending activity, and the maturity structure of bank loans.

- A Second Pillar that includes real, external, and financial indicators of macroeconomic conditions, and may be used to justify deviations from the reference values for M3 and nominal GDP growth. These indicators include the balance of payments, the foreign interest differential, the exchange rate, and net sales of foreign exchange by banks, wages, and the dynamics of controlled prices.

In the context of the announcement of the new framework, the BoS published "reference values" for a number of these indicators, including M3 and M1 growth, public sector wage growth, and oil prices. These forecast values are not viewed as targets, but as guideposts for achieving the inflation objective.

In conducting policy, the BoS will utilize both the exchange rate and interest rate transmission channels. Within the perspective of gradually lowering the pace of depreciation, the BoS will initially continue to use the exchange rate to curtail interest-sensitive capital flows through control of the foreign interest differential. However, in order to discourage short-term capital flows, the BoS will allow greater short-term exchange rate volatility. The BoS will also continue to rely on a range of interest rates to meet its liquidity objectives, including tolar bill rates to achieve the desired amount of sterilization and the foreign exchange swap rate to constrain banks' demand for central bank credit.

As deindexation and the deepening of interbank markets make the interest rate channel more robust, the BoS plans to rely increasingly on interest rates and less on the exchange rate as an instrument. This would represent a significant improvement in signaling policy intentions as compared with the previous regime, in which controlling the foreign interest differential often required changes in interest rates and exchange rates that had opposing effects on monetary conditions. Eventually, monetary conditions could come to be dominated by movements in interest rates.

An important aspect of the new framework is its communications policy. The BoS intends to update and publish every six months its forecasts of a comprehensive set of macroeconomic variables and of the reference values of the first and second pillar variables. The BoS will account for its policy actions on the basis of these forecasts. 


\section{Deindexation of Financial Contracts and the Saving Rate: The International Experience}

Indexation of financial contracts allows the financial system to function in an economy with high and volatile inflation. Lenders trying to protect the real value of their assets and borrowers seeking to cap the real value of liabilities demand indexed financial instruments when inflation is volatile, which is increasingly the case as inflation rises. Therefore, addressing the causes of high inflation is a necessary condition for a successful deindexation effort. Otherwise, agents seek other ways to protect their real returns - such as investing in financial instruments denominated in foreign currencies -or reduce their savings. By providing a way to live with inflation, financial indexation, like any other kind of indexation, may contribute to inflation inertia and reduce pressures for disinflation (although it has also been argued that financial indexation may help disinflation by lowering the incentive of the government to generate unanticipated inflation). In a free market, both indexed and nominal contracts could co-exist, but in a low inflation environment the demand for the former would be low.

Indexation has been widespread in the Slovene financial systern. Hyperinflation in the late 1980 s in the former SFRY and during the years of independence (inflation reached 13,000 percent per annum in late 1989) limited central bank credibility and lowered the population's readiness to internalize disinflation gains in its expectations of future inflation. Indexation for most financial contracts was introduced to help the development of the financial system and boost confidence in the currency. Interest rates for financial instruments of maturities longer than a month are currently quoted in real terms, and a separate, published revaluation clause is added to compensate for past inflation.

Financial deindexation is a major objective of the authorities. However, they are concerned that rapid deindexation might depress saving and boost consumption, and favor a gradual approach, in which contracts of short maturity are deindexed first and those of longer maturity follow.

Country experience has shown that disinflation and deindexation efforts should go hand-inhand to succeed. ${ }^{4}$ As the discussion below shows, both gradual and "shock" approaches to deindexation have worked in countries that followed successful stabilization policies at the same time. Low inflation increases the demand for financial instruments denominated in nominal rates. Often, deindexation has been part of the stabilization policy package, helping to achieve disinflation. The concem that deindexation may reduce private saving has not been borne out by the experience of countries where stabilization was successful.

Iceland and Chile, both with a history of high inflation, followed successfully a gradual approach to deindexation, at the mid-1980s and mid-1990s respectively, together with price

\footnotetext{
${ }^{4}$ The discussion of country experience with deindexation draws from Price, R., 1997,"The Rationale and Design of Inflation-Indexed Bonds," IMF Working Paper (WP/97/12).
} 
stabilization policies, financial market liberalization, and other reforms. The gradual approach, in which shorter maturities were deindexed first, was chosen to avoid a fall in private saving. In the event, deindexation and disinflation were successful in both countries, and private saving actually increased as a percent of GDP after the process of deindexation started (by about 1 percentage point in Iceland and by 2 percentage points in Chile on average in the five-year period following deindexation compared with the five-year period before).

Israel and Brazil's approach was to reduce the demand for indexed financial instruments by reducing inflation, without announcing specific deindexation plans. Stabilization efforts in Israel started in the late 1970 s and continued through the first half of the $1980 \mathrm{~s}$ without success. Only in the second half of the 1980 s was disinflation achieved by fixing the exchange rate and prohibiting central bank financing of the government deficit. While part of the government debt started soon being switched to deindexed instruments, deindexation was left to demand and supply forces. Private saving did not display any strong trend during the second half of the 1980s and in the 1990s, although it fluctuated at a lower level than in the first half of the 1980s. In Brazil, efforts to limit indexation in the financial system by introducing different forms of partial indexation during the 1980s and the beginning of the 1990 s did not succeed, primarily because of failure to reduce inflation. Stabilization policies after 1993 brought inflation down, and the government started offering long-term fixed rate bonds, while allowing the coexistence of both indexed and nominal contracts. Private saving increased as a percent of GDP in the period following disinflation and deindexation (by more than 5 percentage points on average in the five-year period following deindexation compared with the five-year period before).

Finland successfully abolished indexation overnight, while similar attempts in Argentina were less successful. Indexation in both financial and labor markets was prohibited by a government act in Finland in 1968. The act was successful, but Finland already had relatively low inflation (below 10 percent) the years before deindexation. Private saving remained relatively constant as a percent of GDP in the period following deindexation. Argentina formally banned indexation of all contracts with the Convertibility Law in 1991, establishing a currency board arrangement with a parity exchange rate to the U.S. dollar. Although indexed financial contracts disappeared and inflation was reduced to very low levels, most financial contracts with maturities longer than a year were denominated in foreign currency, implying lack of credibility in the system, and private saving declined as a percent of GDP during the 1990s (by more than 4 percentage points on average in the five-year period following deindexation compared with the five-year period before). 


\section{Foreign Bank Participation in Bank Privatization: Theory and Empirical Evidence}

This Appendix reviews the theoretical arguments against and in support of foreign bank participation in bank privatization and the available empirical evidence. While the theoretical arguments are divided, the empirical evidence suggests that foreign bank entry improves the functioning of the financial system, enhances its efficiency by increasing competition and reducing overhead expenses, lowers the risk of a banking crisis, supports economic growth, and improves the financing conditions for the private sector by reducing interest rates margins and overhead costs and contributing to the stability of credit flows. While these empirical conclusions are very firm, it should be noted that they are drawn from the experience of a diverse group of emerging markets. As such, they may not directly apply to Slovenia.

Foreign bank entry in emerging markets increased tremendously in the $1990 \mathrm{~s}$, in hand with liberalization and privatization in the financial sector. In several emerging markets, foreign banks have more than 50 percent of total banking assets (Argentina, Chile, Czech Republic, Hungary, Poland, and Estonia). And in many other countries, foreign bank penetration in the domestic market has been steadily increasing.

There is a wide consensus that privatization improves commercial banks' performance, resulting in positive spillover effects for the economy as a whole. Studies have found that banks experience considerable improvements in profitability and operating efficiency after privatization in samples of both industrial and emerging economies. ${ }^{5}$ In emerging economies, private ownership in the banking sector has accelerated financial sector development, per capita income, and productivity growth. ${ }^{6}$

However, as regards to foreign participation in the privatization of banks-and, more broadly, foreign bank entry--the theoretical debate is inconclusive. ${ }^{7}$ The main arguments in favor of foreign participation are that

\footnotetext{
${ }^{5}$ J. D'Souza and W. L. Megginson, 1999, "The Financial and Operating Performance of Privatized Firms during the 1990s," Journal of Finance LIV, 1397-1438.
}

${ }^{6}$ Rafael La Porta, Florenzio Lopez-de-Silanes, and Andrei Shleifer, 1999, "Government Ownership of Banks," Harvard University mimeo.

${ }^{7}$ For more details see G. Dages, L. Goldberg, and D. Kinney, 2000, "Foreign and Domestic Bank Participation in Emerging Markets: Lessons from Mexico and Argentina," Economic Policy Review, pp.17-36. 
- foreign banks increase liquidity and reduce the volatility of available credit by facilitating capital inflows and diversifying the sources of credit, which allows the economy to absorb shocks better;

- foreign banks improve the quality, pricing and availability of financial services by providing a wide range of such services and by competing with domestic banks;

- foreign banks improve the infrastructure of the financial system by introducing better practices of measuring and managing risk and increasing the presence of foreign supporting agents, such as ratings agencies and auditors; and

- in emerging markets, allowing foreign bank participation in the privatization of the banking sector is often a necessary condition for higher competition and new technologies, as well as for reducing connected lending.

There have also been arguments against foreign participation in bank privatization.

- foreign banks reduce financial stability by facilitating capital flight and withdrawing rapidly from domestic markets during a crisis in the host or home country;

- entry of foreign banks results in market segmentation by "cherry-picking" the best quality debtors and leaving the more risky clients to domestic banks; and

- information asymmetries and differences in the complexity of the financial systems in the home and host countries raise challenges for the supervision of foreign banks.

The available empirical evidence, however, conclusively supports the view that foreign bank entry improves the functioning of the financial system. Cross-country studies have found that foreign bank presence enhances efficiency by increasing competition and reducing overhead expenses for domestic banks. ${ }^{8}$ The presence of foreign banks in the financial system lowers the probability of a banking crisis, and by increasing the efficiency of the financial system supports economic growth. ${ }^{9}$ Firm-level, cross-country data have shown that foreign bank penetration improves the financing conditions of all firms, including small- and

${ }^{8}$ S. Claessens, A. Demirguc-Kunt, and H. Huizinga. 1998, "How Does Foreign Entry Affect the Domestic Banking Market?", Policy Research Working Paper 1918, The World Bank.

${ }^{9}$ A. Demirguc-Kunt, R. Levine, and H. Min, 1998, "Opening to Foreign Banks: Issues of Stability, Efficiency, and Growth," in S. Lee, ed., The Implications of Globalization of World Financial Markets, Bank of Korea, Seoul. 
medium-size enterprises, by reducing interest rates margins and overhead costs and by expanding total lending. ${ }^{10}$

Country studies have found similar results. In Colombia, foreign bank entry in the early 1990s enhanced operating efficiency and increased competition in the financial sector, a result that holds even after controlling for other liberalization related factors. ${ }^{11}$ However, the loan quality of domestic banks deteriorated, which suggests that market segmentation did occur. In Mexico and Argentina, foreign bank credit was less volatile than domestic bank credit during the second half of the $1990 \mathrm{~s}$, and, therefore, contributed to the stability of available credit. ${ }^{12}$ In Hungary, a policy of allowing foreign dominance in the banking sector contributed to the stability of the sector in the second half of the 1990s, and produced competitive pressures that benefited the economy as a whole. ${ }^{13}$

${ }^{10}$ G. R. G. Clarke, R. Cull, and M. S. M. Peria, 2001, "Does Foreign Bank Penetration Reduce Access to Credit in Developing Countries? Evidence from Asking Borrowers," World Bank, Washington D.C.

${ }^{11}$ A. Barajas, R. Steiner, and N. Salazar, 1999, "Foreign Investment in Colombia's Financial Sector," IMF Working Paper (WP/99/150).

${ }^{12}$ G. Dages, L. Goldberg, D. Kinney, 2000, "Foreign and Domestic Bank Participation in Emerging Markets: Lessons from Mexico and Argentina," Economic Policy Review, pp.1736; and G. Clarke, R. Cull, L. D'Amato, and A. Molinari, 2000, "On the Kindness of Strangers? The Impact of Foreign Entry on Domestic Banks in Argentina," in S. Claessens and P. Low, eds., Internalization of Financial Services, Kluwer, Dordrecht.

${ }^{13}$ I. Abel and P. L. Siklos, 2001, "Secrets to the Successful Hungarian Bank Privatization: The Benefits of Foreign Ownership," National Bank of Hungary. 
Public Information Notice (PIN) No. 02/39

FOR IMMEDIATE RELEASE

April 4, 2002
International Monetary Fund

$70019^{\text {th }}$ Street, NW

Washington, D. C. 20431 USA

\section{IMF Concludes 2001 Article IV Consultation with the Republic of Slovenia}

On March 20, 2002, the Executive Board of the International Monetary Fund (IMF) concluded the Article IV consultation with the Republic of Slovenia. ${ }^{1}$

\section{Background}

Benefiting from strict macroeconomic discipline, Slovenia is currently among the most successful transition economies. Tight fiscal discipline and a monetary policy based on monetary targeting and a managed float for the tolar brought inflation to the single digits since 1996; kept government debt to about 25 percent of GDP; maintained strong competitiveness and a balanced current account for most of the 1990s; and earned it the highest investment rating and per capita income among transition countries.

Economic growth slowed in 2001 from around 4.5 percent to about 3 percent as domestic demand fell sharply and external demand weakened. Competitiveness remained strong and the current account deficit narrowed to about $1 / 2$ percentage point of GDP. Real export growth decelerated from 12.7 percent in 2000 to 7.9 percent in the first three quarters of 2001.

\footnotetext{
${ }^{1}$ Under Article IV of the IMF's Articles of Agreement, the IMF holds bilateral discussions with members, usually every year. A staff team visits the country, collects economic and financial information, and discusses with officials the country's economic developments and policies. On return to headquarters, the staff prepares a report, which forms the basis for discussion by the Executive Board. At the conclusion of the discussion, the Managing Director, as Chairman of the Board, summarizes the views of Executive Directors, and this summary is transmitted to the country's authorities. This PIN summarizes the views of the Executive Board as expressed during the March 20, 2002 Executive Board discussion based on the staff report.
} 
The inflation rate had been stuck at the 9-10 percent range since mid-1999, reflecting a combination of successive exogenous shocks (VAT, energy costs, administered prices) and an accommodating monetary stance. However, the unwinding of these shocks and progressive tightening of monetary conditions during 2001 brought average inflation in 2001 down to 8.4 percent and end-year inflation to 7 percent.

The planned reduction in the budget deficit in 2001 did not materialize because of expenditure overruns. The 2001 budget aimed at a general government deficit of 1 percent of GDP, down from 1.4 percent of GDP in 2000 . In the event, higher-than-budgeted wage, consumption, and pension outlays resulted in a general government deficit of 1.3 percent of GDP in 2001.

Monetary policy was gradually tightened during 2001, although capital inflows kept broad liquidity high. Interest rates were raised in March and remained unchanged until November, when they were eased as inflation pressures abated; the pace of the depreciation of the tolar slowed from an annual rate of about 8-9 percent in the first half to about 4.5 percent in the second half; and domestic credit and base money growth were contained. This tightening of monetary conditions helped curb inflation in late 2001. However, capital account liberalization and foreign direct investment inflows boosted broad liquidity.

The pace of structural reforms accelerated in 2001. A new basic budget law was passed, stipulating two-year budgets starting in 2002. Backward-looking full wage indexation was abandoned in favor of partial indexation to projected inflation in both the public and the private sectors in 2001. The government decided to close the Slovene Development Corporation, a government holding company with shares in loss-making enterprises, and lowered its stake in Telekom Slovenije. The privatization of two large state-owned banks is proceeding slowly, and there is considerable opposition to foreign participation in the privatization process. Also, insurance company privatization is stalled by a court challenge.

Growth is not expected to pick up in 2002 as foreign demand is likely to slow further and domestic investment to recover only gradually. The 2002 budget aims at a small reduction in the general government deficit to 1.1 percent of GDP and a further increase in the expenditure-toGDP ratio. However, the cash deficit will reach 2.6 percent of GDP as the budget accounting will be shifted onto pure cash basis in 2002, discontinuing the practice of booking in the current year revenues accrued in December but collected the following January. The Bank of Slovenia has announced an inflation goal of 5.8 percent for end 2002, notwithstanding the increase in the VAT rate in January 2002.

\section{Executive Board Assessment}

Directors noted that Slovenia is among the most successful transition economies and well advanced in terms of convergence and smooth economic integration with the European Union. They commended the Slovene authorities for their strategy of strict macroeconomic discipline, strong efforts at institutional development, and recent progress in structural reforms, which have led to broad-based sustainable growth and strong competitiveness. Directors welcomed the 
recent decline in inflation after more than two years of persistently higher rates, and the improvement in the current account in 2001.

Directors, noting the uncertain near-term outlook, emphasized the need for a stable policy environment to support private sector economic activity and promote medium-term growth. In this context, they endorsed the authorities' intention to keep policies focused on medium-term goals. They noted that allowing automatic fiscal stabilizers to work would have only limited benefits in a small and very open economy like Slovenia, which would be outweighed by the costs of a rapidly rising deficit. Therefore, they supported the government's intention to limit the operation of automatic stabilizers in 2002 , noting that this would likely require restraining expenditure relative to budgeted levels.

Directors underscored the advantages of an appropriate medium-term fiscal policy framework. They endorsed the authorities' medium-term goal of a balanced budget, and emphasized in particular the need to place the expenditure-to-GDP ratio on a downward path, reversing its recent upward creep. Directors considered the introduction of a rolling two-year budget framework a positive step, but called for supplementing it with a fully fledged medium-term expenditure plan that would aim to reduce the overall spending ratio while accommodating new expenditures associated with European Union and NATO accession. This would require reducing the share of public wages and social transfers, which constitute the bulk of public spending, through changes in the public wage determination system and reforms to improve the efficiency and targeting of social transfers.

Directors agreed that the authorities should capitalize on the opportunity provided by the easing of exogenous price pressures to consolidate the downward trend in inflation in 2002. They therefore welcomed the new monetary policy framework's focus on disinflation and urged the authorities to maintain a tight monetary policy. They noted however that the framework remains discretionary and, therefore, that its effectiveness would depend on how it is implemented, in particular in conditions of increased liquidity caused by capital account liberalization. In this respect, many Directors considered that exchange rate policy should be subordinated to the goal of disinflation, especially in the event of large capital inflows, although it was also noted that with continued skifful and pragmatic coordination of exchange rate and short-term interest rate policies, speculative capital flows could be mitigated, the inflation objective achieved, and policy credibility enhanced. Directors underlined the importance of effective communication by the Bank of Slovenia to explain its policy actions to the public, and the need to enhance coordination with fiscal and administered price policies. Directors felt that, in the medium term, moving to a formal inflation targeting framework would enhance policy credibility and provide an effective framework for policy within the Exchange Rate Mechanism 2 bands.

Directors commended the authorities for the Financial Sector Action Plan they prepared in response to the recommendations of last year's Financial Sector Assessment Program and the considerable progress achieved in strengthening financial sector supervision and improving liquidity management. Directors especially welcomed the adoption of rules limiting connected lending and the progress in consolidated supervision. They noted that these achievements would help the Bank of Slovenia deal with the supervisory challenges arising in the newly 
liberalized and highly integrated financial sector. Directors also welcomed recent steps to develop the money market and deindex financial contracts, and thought that rapid progress in these areas would improve the transmission of monetary policy by promoting the development of market-determined interest rates. Directors commended the authorities for their efforts to combat money laundering and terrorism financing.

Directors encouraged the authorities to move decisively and quickly to privatize two large stateowned banks, which they considered necessary for a more efficient and competitive banking system. They stressed the need for an accelerated privatization approach that is transparent and would create strong, internationally competitive banks with good corporate governance. Directors urged the authorities to be open toward foreign investors in bank privatization, as the Slovene banking system could otherwise be at a disadvantage in the broader European context and discourage foreign investment in other sectors as well.

Directors welcomed the recent acceleration in structural reforms as laying the groundwork for continued rapid convergence of living standards to European Union levels, but saw the need for broadening and deepening the reform measures. Directors urged the authorities to keep up the momentum in liberalization and deregulation in order to enhance the efficiency of the economy and reduce the role of the state. They welcomed the adoption of forward-looking wage indexation, which should promote disinflation, and called for a rapid adoption of the draft Labor Relations Law in order to increase flexibility in the labor market. Directors called for rationalizing extrabudgetary funds by retaining only those that perform public policy functions and applying the same rule to the entity that would succeed the Slovene Development Corporation. Finally, Directors welcomed the assessment in the Report on the Observance of Standards and Codes that Slovenia meets the requirements of the Fiscal Transparency Code in many important respects, and urged the authorities to move forward with its recommended improvements.

Public Information Notices (PINs) are issued, (i) at the request of a member country, following the conclusion of the Article IV consultation for countries seeking to make known the views of the IMF to the public. This action is intended to strengthen IMF surveillance over the economic policies of member countries by increasing the transparency of the IMF's assessment of these policies; and (ii) following policy discussions in the Executive Board at the decision of the Board. The Staff Repart for the 2002 Article IV Consultation with the Republic of Slovenia is also available. 
Slovenia: Selected Economic Indicators

\begin{tabular}{|c|c|c|c|c|c|c|c|c|}
\hline & 1997 & 1998 & 1999 & 2000 & 2001 & & $\begin{array}{l}2002 \\
\text { Staff }\end{array}$ & \\
\hline \multicolumn{9}{|l|}{ Real Economy } \\
\hline Real GDP $1 /$ & 4.6 & 3.8 & 5.2 & 4.6 & 3.1 & & 2.5 & \\
\hline Gross domestic investment (in percent of GDP) $1 /$ & 24.1 & 25.6 & 28.4 & 27.8 & 25.3 & & 25.2 & \\
\hline Gross national savings (in percent of GDP) & 24.1 & 24.8 & 24.5 & 24.4 & 24.9 & & 24.9 & \\
\hline Labor force (in thousands) & 869 & 871 & 877 & 875 & 886 & & 875 & \\
\hline Registered Unemployed & 14.4 & 14.5 & 13.6 & 12.2 & 11.6 & & 11.9 & \\
\hline Unemp loym ent rate (ILO definition) $1 /$ & 7.4 & 7.9 & 7.6 & 7.0 & 6.2 & & 6.5 & \\
\hline Consumer prices (percentage change, end-period) & 8.8 & 6.5 & 8.0 & 8.9 & 7.0 & & 5.8 & \\
\hline Real Gross wages (percentage change, average) & 3.2 & 1.6 & 3.3 & 1.7 & 3.2 & & $\cdots$ & \\
\hline \multicolumn{9}{|l|}{ General Government Finances $2 /$} \\
\hline General government balance 3/ & -1.1 & -0.6 & -0.6 & -1.4 & -1.3 & & -2.6 & $4 /$ \\
\hline Overall balance excluding privatization receipts & -1.7 & -0.9 & -0.9 & -1.4 & -1.6 & & -2.9 & \\
\hline Debt & 23.2 & 23.7 & 24.6 & 25.1 & 25.3 & $5 /$ & 26.0 & \\
\hline \multicolumn{9}{|l|}{ Money and Credit } \\
\hline Broad money (inc. for eign exchange deposits) & 23.8 & 20.9 & 15.1 & 15.3 & 30.4 & & $12-18$ & \\
\hline Credit to the private sector (real; end of period) & 4.7 & 19.3 & 17.8 & 8.7 & 9.3 & & $\ldots$ & \\
\hline \multicolumn{9}{|l|}{ Interest Rates } \\
\hline Nominal interbank interest rate (percent, overnight) & 9.6 & 7.4 & 6.8 & 6.8 & 6.7 & & $\ldots$ & \\
\hline Lending rates (percent) & $16-17$ & $12-13$ & $12-14$ & $15-17$ & $15.1-17.1$ & & $\ldots$ & \\
\hline Deposit rates (percent) & $7-10$ & $4-7$ & $7-10$ & $10-14$ & $9.8-13.7$ & & $\ldots$ & \\
\hline \multicolumn{9}{|l|}{ Balance of Payments } \\
\hline Trade balance (in percent of GDP) & -4.3 & -4.0 & -6.2 & -6.3 & -3.3 & & -3.1 & \\
\hline Current account (in percent of GDP) & 0.1 & -0.8 & -3.9 & -3.4 & -0.4 & & -0.3 & \\
\hline Capital and financial account (in percent of GDP) & 6.6 & 1.2 & 3.4 & 4.1 & 7.0 & & 3.2 & \\
\hline Gross of ficial reserves of the Bank of Slovenia $6 /$ & 3,315 & 3,639 & 3,168 & 3,196 & 4,397 & & 4,880 & \\
\hline (in months of imports of goods and services) & $3 . \overline{8}$ & 3.8 & 3.3 & 3.4 & 4.6 & & 5.0 & \\
\hline External debt (in percent of exports of goods and services) & 39.4 & 44.2 & 51.3 & 58.1 & 59.5 & & $\ldots$ & \\
\hline \multicolumn{9}{|l|}{ Exchange Rates } \\
\hline Tolars per U.S. dollar (end-period) & 169.2 & 161.2 & 196.8 & 227.4 & 250.9 & & $\ldots$ & \\
\hline Tolars per euro (end-period) & $\ldots$ & $\ldots$ & 197.3 & 211.5 & 221.4 & & $\ldots$ & \\
\hline Nominal effective exchange rate $(1995=100$, avg.) & 85.4 & 83.2 & 78.0 & 71.5 & 66.1 & & $\ldots$ & \\
\hline Real effective exchange rate (CPI based, 1995=100, avg.) & 97.8 & 100.8 & 100.0 & 97.6 & 97.7 & & $\ldots$ & \\
\hline
\end{tabular}

Sources: Slovene authorities; and Fund staff calculations and projections.

1/Data for 2001 are the average for the first three quarters.

$2 /$ Budget numbers for 2002 .

3/Official statistics: include privatization revenues in net lending.

4/Due to a shift in the budget accounting to a pure cash basis.

5/Debt in September 30, 2001 as a share of projected nominal GDP for 2001.

6/Excludes gold, SDRs, and IMF position. 


\section{Statement by Johann Prader, Alternate Executive Director and Ksenija Maver, Assistant to the Executive Director for the Republic of Slovenia March 20, 2002}

The Slovene authorities wish to thank Mr. Demekas and his team for productive discussions and valuable advice, as well as for their concise and thorough report.

\section{Slovenia: A Small, Very Open Economy}

Following independence in 1991, Slovenia quickly achieved macroeconomic stability and launched systemic structural reforms. From 1993 to 2000, annual growth averaged 4.3 percent but slowed to about 3 percent in 2001 , due both to weaker foreign demand and declining investments. However, recent indicators show that Slovene companies responded to the slowing of economic activity by increasing productivity. This, together with the nascent world recovery, provides a basis for optimism about Slovenia's prospects in 2002 and later years.

The current account and the fiscal deficit are now at moderate levels; the public debt-toGDP ratio is 25 percent; and the total external debt-to-exports ratio is 57 percent. Slovenia's economic position can be considered strong. Inflation declined from 201 percent in 1992 to 6 percent in 1999, and after a short spike in 2000, was 7 percent at the end of 2001. In the first two months of this year, this favorable trend was interrupted when inflation rose to 8 percent, due to a recent rise in the taxation of tobacco and alcohol, and an increase in the VAT and some administered prices. However, the interruption is seen as temporary.

Slovenia's transition has involved two especially demanding challenges: first, the agenda of EU accession; and second, the problems peculiar to small, open economies.

The first challenge, the run up to EU and EMU membership, placed significant demands on macroeconomic management, especially in the field of public finance and monetary policy. Until today, Slovenia reviewed and closed 26 of the total 29 chapters of the EU legal norms, i.e. the Acquis communautaire, and hopes to conclude EU accession negotiations by the end of 2002. Under the optimistic scenario Slovenia would enter the EU in 2004, soon after that join the ERM 2, and adopt the euro in 2006.

The second challenge, mastering the problems of a small open economy in transition, required finding innovative solutions that sometimes differed from textbook examples. Slovenia's gradual and prudent approach to stabilization and structural reforms has clearly proved its worth. For example, the cautious attitude toward capital account liberalization enabled the economy to cope remarkably well with financial crises.

These same two challenges had also to be taken into account by monetary and fiscal policy, and by the bank privatization process. 


\section{Monetary and Exchange Rate Policy}

Since its establishment in 1991, the Bank of Slovenia's primary goal of achieving and maintaining price stability has remained unchanged, and its strategy combining monetary targeting and a managed float exchange rate regime has been successful.

In November 2001, the Bank of Slovenia set the monetary framework for the period leading up to EU accession, and for the later period before accession to ERM 2. The framework establishes medium-term targets for the further reduction of inflation, to 5.2-5.7 percent by the end of 2002 and 3.5-4.2 percent by the end of 2003.

And all the way up to Slovenia's accession to ERM 2, the central bank will monitor, similarly to the ECB's monetary policy, two pillars. The first is money in circulation, i.e. all indicators that as far as possible directly reflect the behavior of $\mathrm{M} 3$ and its individual components. ${ }^{1}$ The second consists of indicators that explain the economic situation (in particular the exchange rate, interest rates and interest rate spreads, balance-of-payments indicators, wages, and administered prices).

Given the greater uncertainty that characterizes small open economies, and the short time since capital account and financial liberalization, this strategy has many advantages over an explicit targeting of inflation. In principle, up until accession to the EU, the central banks of accession countries have an entirely free hand in choosing an exchange rate regime and the strategy of monetary policy targeting and implementation. The Bank of Slovenia will make every effort to ensure a smooth transition to the new and demanding EU environment.

This does not imply that the managed float exchange regime gives the central bank complete discretion in its operations. The $\mathrm{BoS}$ is using an operating rule that is consistent with a managed floating exchange rate regime, as described in recent academic work. ${ }^{2}$ Under this operating rule, equilibrium is obtained by targeting the uncovered interest rate differential vis- $\grave{a}$ vis the euro through the simultaneous and consistent detemination of the exchange rate and the nominal short-term interest rate. This procedure supports the inflation objective by preventing speculative inflows.

\section{Fiscal Policy}

In 2001, Slovenia approved three important documents that provide a medium-term strategic approach to fiscal policy. These are the Medium Term Development Strategy, which

\footnotetext{
${ }^{1}$ E.g., liquidity of the banking system, short-term interest rate movements, structure of monetary aggregates, credit activity of commercial banks.

${ }^{2}$ Bofinger, Peter, and Timo Wollmershaeuser (2001), Managed Floating: Understanding the New International Money Order, Centre for Policy Research, Discussion Paper No. 3064, internet: www.cepr.org/pubs.dpc/DP3064.asp
} 
is the basis of the Pre-accession Economic Program (PEP) for the period until 2005, and the Budget Memorandum for $2002 / 2003$.

The PEP reflects part of Slovenia's dialogue with the EU. Such programs were prepared by all EU accession countries in 2001. Slovenia's PEP sets forth the medium-term fiscal goal of replacing the present low budget deficit with a balanced budget by 2005 . This will be done by imposing strict limits on expenditures. The ratio of general government expenditures to GDP is projected to decrease from 45.2 percent of GDP in 2002 to 42.4 percent in 2005 . The ratio of general govermment revenues to GDP is projected to remain unchanged at 42 or 43 percent of GDP until 2005. This will gradually reduce the gap of 1.3 percent of GDP at the end of 2001 to zero by 2005 .

Crucial for success in reining in the ratio of expenditures to GDP will be the reduction of the wage bill and the interest bill. It is important to note that the growth of public wages will slow this year as a result of the replacement of backward-looking wage indexation by forwardlooking indexation. In addition, the GDP ratio of interest payments will decrease (from 1.61 percent of GDP in 2002 to 1.15 percent of GDP in 2005) as a large portion of the public debt will be retired using privatization proceeds expected to amount to a cumulative 7 percent of annual GDP during the period from 2002 to 2005. Additional measures--such as more efficient use of public funds (subsidies, health) and the transfer of some public services to the private sector--will help reduce government expenditures.

Another important innovation was the introduction of a two-year budget in November 2001. The PEP paved the way for preparation of the Budget Memorandum and of budgets for the period 2002/2003. Using a two-year fiscal framework in budget preparation has the advantage of affording more flexibility in streamlining priorities. In particular, budget users will find it easier to sequence their programs and allocate their resources over a broader time horizon.

The year 2002, with a projected budget deficit of 2.5 percent of GDP, will be difficult, but already in 2003 this deficit is expected to fall to 0.7 percent. So although spending constraints will be especially tight in 2002 , the budget in 2003 and later years will improve and make room for investment and development programs.

Despite the downward trend of the economy, the government will not allow the full play of automatic stabilizers in 2002 because they could compromise the medium-term fiscal strategy. The political commitment to all three documents--the Strategy, the PEP, and the Budget Memorandum--is strong. The measures needed to achieve the projected results are clearly defined. And it is widely recognized that for a small open economy like Slovenia's a fiscal deficit is undesirable. The prospects for achieving the goals defined by these three documents are therefore good. 


\section{Bank Privatization}

The banking sector reforms launched by Slovenia in 1993 started with the rehabilitation of commercial banks that were near bankruptcy. The state issued bonds worth some 10 percent of that year's GDP, purged the banks' portfolios of bad assets, and worked to resolve inherited problems (e.g., foreign debts) that burdened their balance sheets. During the process, two of the three banks being rehabilitated merged. And since 1997 the two newly rehabilitated banks have been highly profitable.

Before their rehabilitation was complete, privatizing these banks was not feasible. And because Slovenia's external position was strong, there was no need to unload them quickly on foreign buyers. The state preferred instead to ready them for the tough market conditions ahead.

The privatization of the two banks began in 2001 with the government's program calling for the partial privatization of the Nova Ljubljanska Banka ( 48 percent) and the Nova Kreditna Banka Maribor (65 percent).

Negotiations with potential buyers (mostly from neighboring countries) are presently under way, so the final outcome is not yet known. The selection process is cognizant of the two goals set by the government's privatization program adopted last year: first, the privatization should strengthen competitiveness and efficiency of the banking system, and second, the government intends to hold out for a good financial result, so that the proceeds of the banks' privatization can be applied to reimburse the government's costs contiected with their rehabilitation.

The staff has provided valuable insights into the theoretical arguments and empirical evidence concerning the pros and cons of allowing foreign banks to participate in bank privatization. Bank privatization should also be viewed in the light of its monetary and fiscal effects on the economy. Changing the ownership structure of banks in which the state still holds a majority stake presents a special challenge for the entire Slovene economy. 